\title{
Monsoon-facilitated characteristics and transport of atmospheric mercury at a high-altitude background site in southwestern China
}

\author{
Hui Zhang ${ }^{1}$, Xuewu Fu ${ }^{1}$, Che-Jen Lin ${ }^{1,2}$, Lihai Shang ${ }^{1}$, Yiping Zhang ${ }^{3}$, Xinbin Feng ${ }^{1}$, and Cynthia Lin ${ }^{4}$ \\ ${ }^{1}$ State Key Laboratory of Environmental Geochemistry, Institute of Geochemistry, Chinese Academy of Sciences, Guiyang \\ 550081, China \\ ${ }^{2}$ Center for Advances in Water and Air Quality, Lamar University, Beaumont, TX 77710, USA \\ ${ }^{3}$ Xishuangbanna Tropical Botanical Garden, Chinese Academy of Sciences, Kunming 650223, China \\ ${ }^{4}$ The McKetta Department of Chemical Engineering, The University of Texas at Austin, Austin, TX 78712, USA \\ Correspondence to: Xinbin Feng (fengxinbin@vip.skleg.cn), Xuewu Fu (fuxuewu@mail.gyig.ac.cn)
}

Received: 14 June 2016 - Published in Atmos. Chem. Phys. Discuss.: 23 June 2016

Revised: 22 September 2016 - Accepted: 30 September 2016 - Published: 26 October 2016

\begin{abstract}
To better understand the influence of monsoonal climate and transport of atmospheric mercury $(\mathrm{Hg})$ in southwestern China, measurements of total gaseous mercury (TGM, defined as the sum of gaseous elemental mercury, GEM, and gaseous oxidized mercury, GOM), particulate bound mercury (PBM) and GOM were carried out at Ailaoshan Station (ALS, $2450 \mathrm{~m}$ a.s.1.) in southwestern China from May 2011 to May 2012. The mean concentrations $( \pm \mathrm{SD})$ for TGM, GOM and PBM were $2.09 \pm 0.63,2.2 \pm 2.3$ and $31.3 \pm 28.4 \mathrm{pg} \mathrm{m}^{-3}$, respectively. TGM showed a monsoonal distribution pattern with relatively higher concentrations $\left(2.22 \pm 0.58 \mathrm{ng} \mathrm{m}^{-3}\right.$, $p=0.021$ ) during the Indian summer monsoon (ISM, from May to September) and the east Asia summer monsoon (EASM, from May to September) periods than that $\left(1.99 \pm 0.66 \mathrm{ng} \mathrm{m}^{-3}\right)$ in the non-ISM period. Similarly, GOM and PBM concentrations were higher during the ISM period than during the non-ISM period. This study suggests that the ISM and the EASM have a strong impact on longrange and transboundary transport of $\mathrm{Hg}$ between southwestern China and south and southeast Asia. Several high TGM events were accompanied by the occurrence of northern wind during the ISM period, indicating anthropogenic Hg emissions from inland China could rapidly increase TGM levels at ALS due to strengthening of the EASM. Most of the TGM and PBM events occurred at ALS during the non-ISM period. Meanwhile, high $\mathrm{CO}$ concentrations were also observed at ALS, indicating that a strong south tributary of westerlies could have transported $\mathrm{Hg}$ from south and southeast Asia to
\end{abstract}

southwestern China during the non-ISM period. The biomass burning in southeast Asia and anthropogenic Hg emissions from south Asia are thought to be the source of atmospheric $\mathrm{Hg}$ in remote areas of southwestern China during the nonISM period.

\section{Introduction}

Mercury ( $\mathrm{Hg})$, because of its volatility and long residence time in atmosphere, can transport a long distance with air mass from anthropogenic $\mathrm{Hg}$ emission regions to remote areas (Schroeder and Munthe, 1998; Pirrone et al., 2010). The monsoonal climate has the potential to strongly affect the transport and distribution of atmospheric $\mathrm{Hg}$ in monsoon regions, such as east and south Asia. The onset of ISM in May causes air masses, originating from the Indian Ocean, to overpass south and southeast Asia, and move northeastwardly to mainland China. Air pollutants such as $\mathrm{SO}_{2}$ and $\mathrm{CO}$ also travel into mainland China via air transport caused by the ISM (Xu et al., 2009; Bonasoni et al., 2010; Lin et al., 2013). In addition, the south tributary of westerlies, which passes over northern India and Myanmar into southwestern China, can also carry air pollutants to southwestern China and the Tibetan Plateau (Loewen et al., 2007; Xu et al., 2009; Yao et al., 2012). In east Asia, EASM is the dominant monsoon. During the monsoon period (from May to September), the warm and moist air masses from the Pacific Ocean sweep through the coastal area of China into inland China, 
and then move across southwestern China and the eastern Tibetan Plateau. During the non-ISM period (from October to April), the dry and cold air masses from Siberia and central Asia move through mainland China into the Pacific Ocean via the westerlies (Hsu, 2005; Fan et al., 2013; Yu et al., 2015). The monsoonal wind changes play an important role in the transport of regional $\mathrm{Hg}$ emissions in southeast and east Asia (Sheu et al., 2010; Tseng et al., 2012; Lee et al., 2016).

An increasing number of studies have indicated that pollutant emissions and transport originate from developing countries in south and southeast Asia (Wang et al., 2009, 2015; Lawrence and Lelieveld, 2010; Bonasoni et al., 2010), home to more than a billion people with strong energy demands, can impact other regions. These areas are regarded as important source regions of many air pollutants that pose significant health risks locally and regionally (Rajgopal, 2003; Lelieveld et al., 2001). Previous studies indicated that $\mathrm{Hg}$ emissions within south and southeast Asia, including southwestern China, have significant impacts on the distribution and deposition of atmospheric $\mathrm{Hg}$ in south and east Asia (Pirrone et al., 2009; Mukherjee et al., 2009; Sheu et al., 2013; Fu et al., 2015; Zhang et al., 2012). These influences have raised concerns about high atmospheric Hg levels in India and southwestern China, and increased $\mathrm{Hg}$ contents in the snow packs of Hindu Kush Himalayan-Tibetan glaciers (Loewen et al., 2005, 2007; Kang et al., 2016). Previous studies reported that the open biomass burning in forests and agricultural waste burning in southeast Asia are major sources of atmospheric $\mathrm{Hg}$, aerosols and persistent organic pollutants in the region, which are subject to transboundary transport (Reid et al., 2013; Chang et al., 2013; Zhang et al., 2010, 2015; Sheu et al., 2013; Wang et al., 2015). However, studies with respect to $\mathrm{Hg}$ emissions in south and southeast Asia and the associated transboundary transport mediated by monsoonal weather are still lacking.

In this study, we conducted comprehensive measurements of TGM, GOM and PBM at Ailaoshan Station (ALS), a remote site in southwestern China. ALS is located in the subtropical mountainous region of the Yunnan province and is close to south and southeast Asia. The air flow to ALS is mainly controlled by the Indian monsoon climate with plenty of rainfall ( $85 \%$ of the total annual rainfall occurred during the ISM period) and also can be affected by EASM during the spring through early fall. In the winter, the weather is controlled by dry and cold monsoon circulation including westerlies and the cold Siberian current (W. Y. Liu et al., 2003; Yuhong and Yourong, 1993; Zhao et al., 2006). Therefore, ALS is a unique location for studying the long-range and transboundary transport of $\mathrm{Hg}$ influenced by the ISM and the EASM.

In this paper, we present the observations of TGM, GOM and PBM during the ISM and non-ISM periods at ALS, and discuss the transboundary transport characteristics using backward trajectory analysis. We also assess the po- tential contributing sources of $\mathrm{Hg}$, and analyze the pathways of transboundary transport. This study is part of the Global Mercury Observation System (GMOS, http://www. gmos.eu/), which aims to establish a global mercury monitoring network for ambient concentrations and deposition of $\mathrm{Hg}$ though ground-based observational platforms, oceanographic and aircraft campaigns (Sprovieri et al., 2013).

\section{Materials and methods}

\subsection{Measurement site descriptions}

This study was conducted at Ailaoshan Mountain National Natural Reserve $\left(24^{\circ} 32^{\prime} \mathrm{N}, 101^{\circ} 01^{\prime} \mathrm{E}\right)$ which lies in the Yunnan province of southern China, a protected forest section covering 5100 ha on the northern crest of a pristine evergreen broadleaved forest on Mt. Ailao $\left(23^{\circ} 35^{\prime}-24^{\circ} 44^{\prime} \mathrm{N}, 100^{\circ} 54^{\prime}-\right.$ $\left.101^{\circ} 01^{\prime} \mathrm{E}\right)$. The forest altitude ranges from 2450 to $2650 \mathrm{~m}$ above sea level (a.s.l.). The climate is influenced by both ISM and EASM during warm seasons with plenty of rainfall (Table 1). On the contrary, the dry and cold monsoon circulation from the south tributary of westerlies control the climate of Mt. Ailao in the winter (Table 1). Annual mean air temperature and rainfall in the study area are $11.3{ }^{\circ} \mathrm{C}$ and $1947 \mathrm{~mm}$, respectively (You et al., 2012). Mt. Ailao is regarded as the largest tract $\left(504 \mathrm{~km}^{2}\right)$ of natural evergreen broadleaved forest and one of China's most important natural areas which has remained relatively undisturbed by human influences due to poor access (W. Liu et al., 2003). Situated about $160 \mathrm{~km}$ to the south of Kunming, the capital of the Yunnan province, ALS is relatively isolated from large anthropogenic $\mathrm{Hg}$ sources. The nearest populated center is Jingdong County (population: 36 500; $1200 \mathrm{~m}$ a.s.l.), located $20 \mathrm{~km}$ to the south. Hg emissions in the Jingdong area are relatively low, ranging between 5 and $10 \mathrm{~g} \mathrm{~km}^{-2}$, as displayed in Fig. 1.

\subsection{Sampling methods and analysis}

\subsubsection{Measurements of atmospheric TGM, GOM and PBM}

From May 2011 to May 2012, TGM (GEM plus GOM) in ambient air was measured every $5 \mathrm{~min}$ with an automated mercury vapor analyzer, Tekran model 2537A (Tekran Inc., Toronto, Canada), which is widely used for monitoring atmospheric $\mathrm{Hg}$. The automated instrument collects $\mathrm{Hg}$ on gold cartridges and then thermally desorbs and detects the $\mathrm{Hg}$ by cold vapor atomic fluorescence spectroscopy (CVAFS). The Tekran 2537A performs automatic calibration for TGM every $73 \mathrm{~h}$ using an internal permeation source. To evaluate these automated calibrations, manual external injections using Tekran 2505 with known concentrations of $\mathrm{Hg}$ were performed every 4 months. PBM $(\leq 0.2 \mu \mathrm{m})$ were collected using a $47 \mathrm{~mm}$ diameter Teflon filter (pore size $0.2 \mu \mathrm{m}$ ). To 
Table 1. The statistics for mercury species and meteorological variables based on daily averages from May 2010 through May 2011 at the ALS site.

\begin{tabular}{|c|c|c|c|c|c|c|c|c|}
\hline & & Spring & Summer & Autumn & Winter & ISM period & $\begin{array}{l}\text { Non-ISM } \\
\text { period }\end{array}$ & Total \\
\hline \multirow{3}{*}{$\begin{array}{l}\text { TGM } \\
\left(\mathrm{ng} \mathrm{m}^{-3}\right)\end{array}$} & Mean & 2.18 & 2.20 & 1.92 & 2.04 & 2.22 & 1.99 & 2.09 \\
\hline & SD & 0.67 & 0.60 & 0.64 & 0.58 & 0.58 & 0.66 & 0.63 \\
\hline & Range & $1.01-5.70$ & $1.15-3.79$ & $1.11-3.59$ & $0.99-4.45$ & $1.01-3.79$ & $0.99-5.70$ & $0.99-5.70$ \\
\hline \multirow{3}{*}{$\begin{array}{l}\text { GOM } \\
\left(\operatorname{pg~m}^{-3}\right)\end{array}$} & Mean & 2.31 & 2.04 & 3.42 & 1.83 & 2.45 & 2.06 & 2.22 \\
\hline & SD & 1.79 & 1.39 & 2.99 & 2.85 & 2.08 & 2.40 & 2.28 \\
\hline & Range & $0.13-10.20$ & $0.27-6.68$ & $0.11-13.29$ & $0.12-17.25$ & $0.11-13.29$ & $0.12-17.25$ & $0.11-17.25$ \\
\hline \multirow{3}{*}{$\begin{array}{l}\text { PBM } \\
\left(\mathrm{pg} \mathrm{m}^{-3}\right)\end{array}$} & Mean & 22.39 & 32.19 & 46.28 & 31.97 & 36.38 & 27.36 & 31.27 \\
\hline & $\mathrm{SD}$ & 19.05 & 30.56 & 28.80 & 30.63 & 30.62 & 26.09 & 28.44 \\
\hline & Range & $0.87-135.79$ & $5.84-165.01$ & $16.16-120.99$ & $3.84-139.65$ & $5.84-165.01$ & $0.87-139.65$ & $0.87-165.01$ \\
\hline \multirow{3}{*}{$\begin{array}{l}\mathrm{AT} \\
\left({ }^{\circ} \mathrm{C}\right)\end{array}$} & Mean & 13.36 & 15.53 & 11.42 & 6.96 & 15.45 & 8.93 & 11.95 \\
\hline & $\mathrm{SD}$ & 3.03 & 1.19 & 3.39 & 1.88 & 1.29 & 2.93 & 3.99 \\
\hline & Range & $4.88-18.38$ & $11.66-17.74$ & $4.78-16.18$ & $1.65-10.83$ & $11.32-18.38$ & $1.65-15.16$ & $1.65-18.38$ \\
\hline \multirow{3}{*}{$\begin{array}{l}\mathrm{RH} \\
(\%)\end{array}$} & Mean & 72.26 & 90.77 & 91.11 & 73.58 & 87.43 & 75.77 & 81.17 \\
\hline & $\mathrm{SD}$ & 15.06 & 5.56 & 4.94 & 18.17 & 9.58 & 17.48 & 15.49 \\
\hline & Range & $38.42-97.63$ & $71.17-99.25$ & $79.96-100.00$ & $33.17-100.00$ & $52.25-99.25$ & $33.17-100.00$ & $33.17-100.00$ \\
\hline \multirow{3}{*}{$\begin{array}{l}\text { WS } \\
\left(\mathrm{ms}^{-1}\right)\end{array}$} & Mean & 3.60 & 2.59 & 2.71 & 4.29 & 2.59 & 3.80 & 3.29 \\
\hline & & 0.42 & 0.47 & 0.38 & 0.07 & 0.45 & 0.55 & 0.79 \\
\hline & Range & $2.99-3.95$ & $2.05-3.19$ & $2.17-2.97$ & $4.20-4.37$ & $2.05-3.19$ & $2.97-4.37$ & $2.05-4.37$ \\
\hline $\begin{array}{l}\text { RF } \\
(\mathrm{mm})\end{array}$ & Total & 334.3 & 845.4 & 612.4 & 44.2 & 1493 & 343.3 & 1836.3 \\
\hline \multirow{2}{*}{$\begin{array}{l}\mathrm{CO} \\
(\mathrm{ppbv})\end{array}$} & Mean & 286 & & 213.9 & 211.6 & & 254.9 & 254.9 \\
\hline & $\mathrm{SD}$ & 116.1 & & 79.5 & 90.4 & & 111.1 & 111.1 \\
\hline \multirow{4}{*}{$\begin{array}{l}\text { Wind } \\
\text { direction } \\
\text { frequency } \\
(\%)\end{array}$} & $\mathrm{NE}$ & 3.25 & 15.22 & 14.03 & 0 & 11.35 & 5.46 & 7.79 \\
\hline & SE & 9.76 & 14.13 & 20.65 & 4.0 & 16.22 & 10.33 & 13.07 \\
\hline & SW & 86.99 & 66.30 & 64.13 & 95.60 & 71.89 & 84.98 & 78.89 \\
\hline & NW & 0 & 0 & 0 & 0 & 0 & 0 & 0 \\
\hline
\end{tabular}

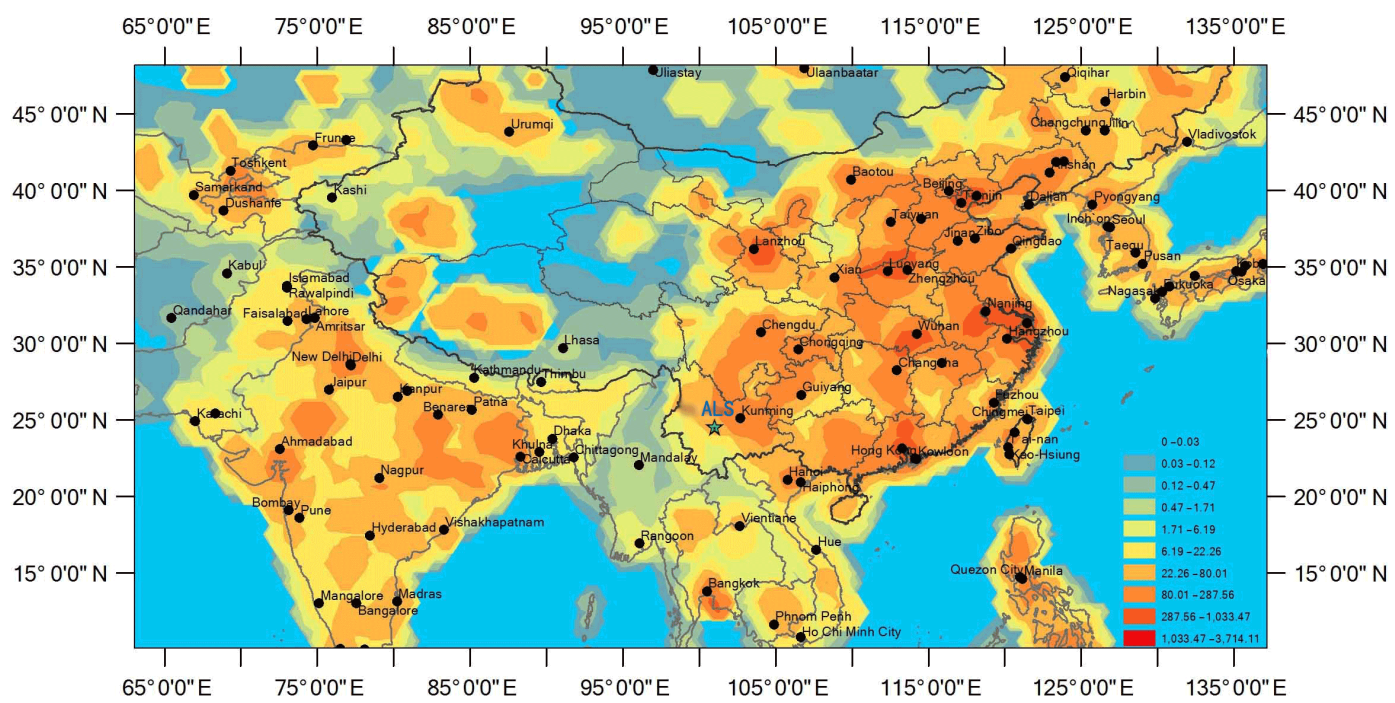

Figure 1. Map showing the location of ALS, anthropogenic mercury emissions $\left(\mathrm{g} \mathrm{km}^{-2} \mathrm{yr}^{-1}\right)$ and major cities in Asia (AMAP/UNEP, 2013). 
prevent the effect of $\mathrm{Hg}$ emission from ground and GOM sorption, the Teflon sampling line with its inlet $5 \mathrm{~m}$ above the ground and heat preservation $\left(50^{\circ} \mathrm{C}\right)$ was employed at the sampling site. To mitigate the influence of low atmospheric pressure on the pump's strain, a low sampling rate of $0.75 \mathrm{~L} \mathrm{~min}^{-1}$ (at standard temperature and pressure) was used (Fu et al., 2008b; Swartzendruber et al., 2009; Zhang et al., 2015).

GOM and PBM was measured using a denuder-based system. The quartz denuders can collect GOM while air passes through the KCl-coated surfaces. However, GOM and PBM have extremely low concentrations and complex chemical reactivities in the atmosphere, and their chemical compounds are not well known. Several previous studies reported that different GOM compounds $\left(\mathrm{HgCl}_{2}, \mathrm{HgBr}_{2}\right.$ and $\left.\mathrm{HgO}\right)$ have different collection efficiencies for the $\mathrm{KCl}$-coated denuder surface, as high relative humidity can passivate $\mathrm{KCl}$-coated denuders and make GOM recoveries decrease (J. Huang et al., 2013; Gustin et al., 2015; Huang and Gustin, 2015). In this study, the measurements of GOM and PBM were achieved by a manual method. The procedure of sampling and analysis of the manual method is analogous to the Tekran speciation system using identical denuders to the Tekran system with $\mathrm{KCl}$ coating (Gustin et al., 2015), differing only by manual operation. Details regarding the measurement system and the quality assurance routines are presented in earlier works (Xiao et al., 1997; Landis et al., 2002; Feng et al., 2000; Fu et al., 2012a; Zhang et al., 2015).

Four sampling campaigns were carried out for PBM and GOM measurements: 17-24 August 2011, 3-17 December 2011, 12-19 April 2012 and 11-21 July 2012. The selected periods represented the ISM period (May-September) and non-ISM period (October-April) observations. Before sampling, the denuders were precleaned by pyrolysis to obtain the filed blanks, which was at $1.2 \pm 0.7 \mathrm{pg}(N=12)$ for denuders. The quartz fiber filter was heated at $900^{\circ} \mathrm{C}$ for $30 \mathrm{~min}$ for precleaning. A somewhat higher field blank $(6.2 \pm 2.7 \mathrm{pg}, N=20)$ was observed and used to correct the PBM concentrations by subtracting the mean blank from the detected Hg. In this study, data QA procedure followed the GMOS standard operation procedure and data quality management (D'Amore et al., 2015).

\subsubsection{Meteorological data and backward trajectory calculation}

Meteorological parameters, including rainfall (RF), wind direction (WD), wind speed (WS), air temperature (AT) and relative humidity $(\mathrm{RH})$, were provided by the local weather station from ALS. In order to identify the influence of longrange transport on the measured $\mathrm{Hg}$ at the study site, 3-day backward trajectories were calculated using HYSPLIT and the Global Data Assimilation System (GDAS) meteorological data archives of the Air Resource Laboratory, National Oceanic and Atmospheric Administration (NOAA). The me-

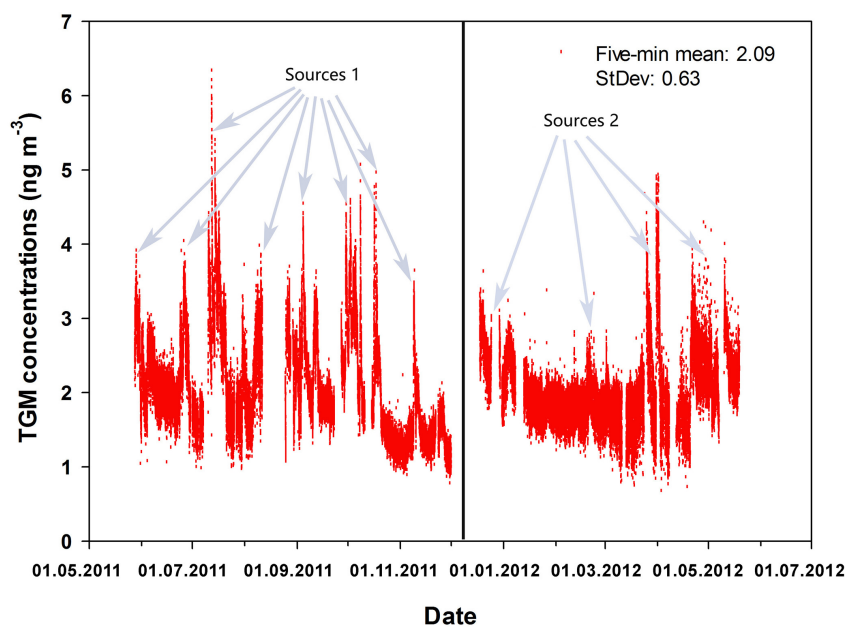

Figure 2. Total gaseous mercury (TGM) concentration in the ambient air at ALS. Source 1 represents the peaks of high TGM concentrations at ALS during the ISM period, which were caused by anthropogenic $\mathrm{Hg}$ emissions from inland China due to the strengthening of EASM. Source 2 represents the peaks of high TGM concentrations at ALS during the non-ISM period, which were caused by the biomass burning from southeast Asia and anthropogenic $\mathrm{Hg}$ emissions from south Asia.

teorological data are of $1^{\circ} \times 1^{\circ}$ spatial resolutions at $6 \mathrm{~h}$ intervals. All the backward trajectories ended at the sampling site at an arrival height of $500 \mathrm{~m}$ above the ground. The backward trajectories were calculated at $1 \mathrm{~h}$ intervals, and cluster analysis of the trajectory endpoints was performed to determine the regional transport pathway. To distinguish the larger sources from moderate sources, a weighing algorithm based on measured concentrations (concentration weighted trajectory, CWT) was applied in this study. In this procedure, each grid cell received a source strength obtained by averaging sample concentrations that have associated trajectories that crossed that grid cell as follows:

$$
C_{i j}=\frac{1}{\sum_{l=1}^{M} \tau i j l} \sum_{l=1}^{M} C_{l \tau i j l} .
$$

$C_{i j}$ is the average weighted concentration in the grid cell $(i, j) . C_{l}$ is the measured $\mathrm{Hg}$ concentration, $\tau_{i j l}$ is the number of trajectory endpoints in the grid cell $(i, j)$ associated with the $C_{l}$ sample and $M$ is the number of samples that have trajectory endpoints in grid cell $(i, j)$. A point filter is applied as the final step of CWT to eliminate grid cells with few endpoints. Weighted concentration fields show concentration gradients across potential sources. This method helps determine the relative significance of potential sources (Hsu et al., 2003; Cheng et al., 2013). 


\section{Results and discussion}

\subsection{General distribution characteristics of TGM, GOM and PBM}

The highly time-resolved long-term data set of TGM concentrations in ambient air at ALS is displayed in Fig. 2, and the mean TGM concentration over the sampling period was $2.09 \pm 0.63 \mathrm{ng} \mathrm{m}^{-3}$ with a higher level $\left(2.22 \mathrm{ng} \mathrm{m}^{-3}\right)$ during the ISM period than that during the non-ISM period $\left(1.99 \mathrm{ng} \mathrm{m}^{-3}\right)$ (Table 1). The TGM mean concentration at ALS was slightly higher than that of the global background $\left(1.5-1.7 \mathrm{ng} \mathrm{m}^{-3}\right.$ in the Northern Hemisphere and $1.1-1.3 \mathrm{ng} \mathrm{m}^{-3}$ in the Southern Hemisphere) (Lindberg et al., 2007; Slemr et al., 2015; Venter et al., 2015), and higher than those (1.58 to $1.93 \mathrm{ng} \mathrm{m}^{-3}$ ) observed in some remote areas in northern America and Europe (Kim et al., 2005; Sprovieri et al., 2010). Compared to the background concentrations observed at the Shangri-La Baseline Observatory in the Yunnan province $\left(2.55 \pm 0.73 \mathrm{ng} \mathrm{m}^{-3}\right.$; Zhang et al., 2015), at Mt. Leigong in the Guizhou province $\left(2.80 \pm 1.51 \mathrm{ng} \mathrm{m}^{-3}\right.$; Fu et al., 2010b) and at Mt. Gongga in the Sichuan province $\left(3.98 \pm 1.62 \mathrm{ng} \mathrm{m}^{-3}\right.$; Fu et al., 2008), the mean TGM level at ALS was lower. However, the mean TGM level at ALS was higher than those observed at Mt. Changbai $\left(1.60 \pm 0.51 \mathrm{ng} \mathrm{m}^{-3}\right)$ in northeast China and at Mt. Waliguan (WLG) Baseline Observatory $\left(1.98 \pm 0.98 \mathrm{ng} \mathrm{m}^{-3}\right)$ in the Tibetan Plateau (Fu et al., 2012a, b). Interestingly, most peaks of high TGM concentrations at ALS frequently appeared during the ISM period (Fig. 2). This differed from the previous results at Mt. Gongga and Mt. Leigong of southwestern China but was similar to the results at Shangri-La. There were also several peaks that appeared during the non-ISM period, which could have been caused by different sources than those during the ISM period. The sampling site is located adjacent to south Asia and southeast Asia, and $\mathrm{Hg}$ emissions from biomass burning in south Asia and southeast Asia would inevitably contribute to the elevated TGM concentrations at ALS during the nonISM period (Wang et al., 2015). Southwestern China is one of the largest $\mathrm{Hg}$ emission areas in China, and coal combustion and non-ferrous metal (especially zinc) smelting activities are the two main $\mathrm{Hg}$ sources. It was reported that total $\mathrm{Hg}$ emission from the Guizhou, Sichuan and Yunan provinces reached about $128 \mathrm{t}$ in 2003 (Wu et al., 2006), and the large amount of $\mathrm{Hg}$ emissions contributed to the elevation of TGM concentrations in this area. Since the Guizhou, Sichuan and Yunan provinces are located in the upper wind direction of the sampling site to EASM, $\mathrm{Hg}$ emission from these areas can be transported to ALS and result in the elevation of TGM concentrations.

Figure 3 displays the distribution frequency of TGM above and under the average $\left(2.09 \mathrm{ng} \mathrm{m}^{-3}\right)$ based on wind direction including northeast (NE), southeast (SE) and southwest (SW) during the ISM and non-ISM period. It is clear that

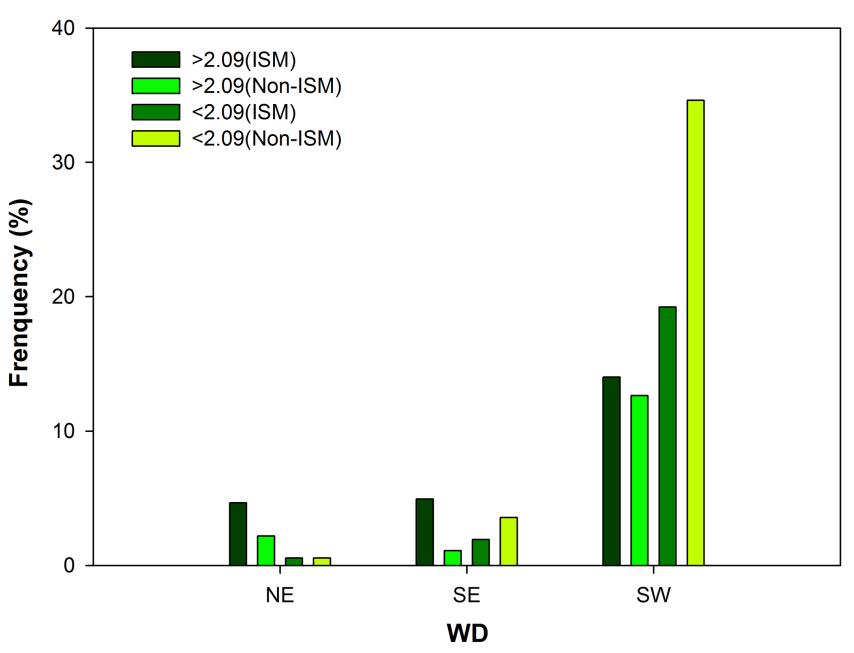

Figure 3. Distribution frequency of TGM above and under the average $\left(2.09 \mathrm{ng} \mathrm{m}^{-3}\right)$ based on wind direction during the ISM and the non-ISM period. The high and low $\mathrm{Hg}$ levels of the SW frequency was higher than both the high and low $\mathrm{Hg}$ levels of the NE and SE frequencies.

SW was the predominating wind direction, and there was no northwest (NW) during the entire study period. The SW frequency was highest when high and low TGM levels occurred during the ISM period or non-ISM period, and the SW frequency showing low TGM was higher than that of high TGM. This could be the reason why the average TGM level from SW was not high. The air flows originating from south Asia and southeast Asia could contribute to high TGM concentrations at ALS. Contrarily, NE and SE frequency had a relatively lower trend than SW, but high TGM frequency from NE and SE were both high during the ISM period. This should be the result from the strengthening of EASM during the ISM period. However, during the non-ISM period, the cold and dry air flow from the south tributary of westerlies could have swept over south Asia and southeast Asia and moved to ALS with high wind speed (Fig. 4). This dry air flow could have also taken the air masses of high $\mathrm{Hg}$ levels emitted from biomass burning in south Asia and southeast Asia to ALS and caused a rapid increase of TGM level at ALS. In addition, cold air flows could also transport $\mathrm{Hg}$ emitted from inland China to ALS due to the strengthening of the cold Siberian current during the non-ISM period. Therefore, there were some high TGM events in December and March at ALS (Fig. 4).

For GOM and PBM, which on average accounted for $<2 \%$ of the TGM, there were also seasonal trends. Both species had the highest levels in autumn while GOM was lowest in the winter and PBM was lowest in the spring. The lowest GOM level was observed in the summer, which increased consistently to reach the highest value $\left(3.4 \pm 3 \mathrm{pg} \mathrm{m}^{-3}\right)$ in autumn. Similarly, PBM displayed the same distribution in seasonal variation, with the highest PBM 


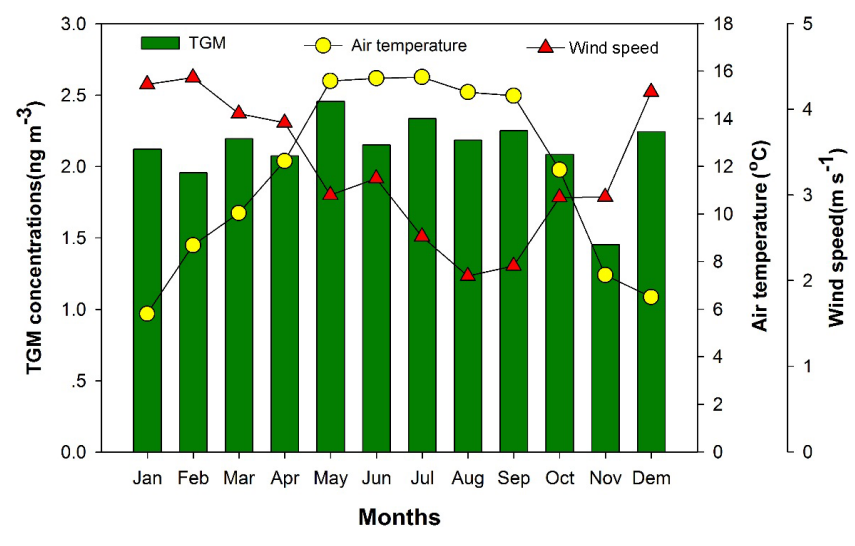

Figure 4. Monthly TGM anomalies at ALS. The Hg concentration during the ISM period (May-September) was higher than that of the non-ISM period (October-April). The highest monthly concentration $\left(2.46 \mathrm{ng} \mathrm{m}^{-3}\right.$ ) was observed in May, and the lowest monthly mean concentration $\left(1.45 \mathrm{ng} \mathrm{m}^{-3}\right)$ was observed in November. The air temperature was higher, and the wind speed was lower during the ISM period than that of the non-ISM period.

level in autumn $\left(46.3 \pm 28.8 \mathrm{pg} \mathrm{m}^{-3}\right)$. Meanwhile, the AT, $\mathrm{RF}$ and RH were also higher during the ISM period than those during the non-ISM period. However, unlike TGM, the GOM and PBM were closely linked with atmospheric $\mathrm{Hg}$ chemistry, meteorological patterns, and numerous other factors. Thus, there are several likely factors that contribute to these trends, including a greater number of sources during the ISM period, and changing ecological or meteorological conditions. Previous studies in the Mt. Gongga and Mt. Leigong area suggested that enhanced coal and biomass burning played a significant role in elevated TGM concentrations during cold seasons (Fu et al., 2008, 2010). Enhanced coal and biomass burning during cold seasons is generally driven by the need for residential heating in China. However, in the southern Yunnan province, the air temperature is high during the non-ISM period. Thus, the domestic use of coal is not dominant for residential heating, but rather the agricultural activity in the region including the crop harvesting and the burning of straw. This was probably one of most important reasons for the highly elevated GOM and PBM level at ALS in autumn.

\subsection{Seasonal variation of TGM, GOM and PBM influenced by monsoonal climate}

Table 1 shows seasonal statistics of daily averages for $\mathrm{Hg}$ species and select meteorological parameters which were determined on a seasonal basis and for the year-long data set. TGM during the ISM period was statistically higher than during the non-ISM period (Table S1 in the Supplement). Meanwhile, AT, RF and RH had a distribution with the highest level during the ISM period, and SW frequency had decline with increase of SE and NE frequency during the ISM period.
This suggests the EASM could also influence the climate at ALS during the ISM period, which was consistent with TGM concentration that the site is impacted by regional sources including biomass burning and monsoonal long-range transboundary transport.

To assess the monsoonal variation of TGM concentrations, the distribution of monthly mean TGM concentrations at ALS is shown in Fig. 4. The TGM concentrations during the ISM period were higher than those during the non-ISM period. The highest monthly concentration was observed in May with a mean value of $2.46 \mathrm{ng} \mathrm{m}^{-3}$, and the lowest monthly mean concentration of $1.45 \mathrm{ng} \mathrm{m}^{-3}$ was observed in November. Although there were relatively higher TGM levels in December and January during the non-ISM period, this pattern was generally different from the most common pattern in the Northern Hemispheric which has a summer minimum and winter maximum TGM distribution pattern as observed in many previous studies (Kellerhals et al., 2003; Kock et al., 2005; Fu et al., 2010). There were several possible reasons for this monsoonal distribution pattern of TGM concentrations on ALS.

Firstly, the increase of TGM concentrations during the ISM period could be due to the interaction of the EASM and the ISM, promoting the air masses with high TGM from the areas of anthropogenic Hg emissions to ALS. Generally, ALS is located on the low-latitude highlands of Yunnan in southwestern China which is subject to the interactions between the EASM and the ISM, although most of time, the air flow of Yunnan is mainly controlled by the ISM during the ISM period. However, the strengthening of the EASM or the weakening of the ISM can also spur the EASM to control this area and bring precipitation during the ISM period (Fan et al., 2013). Therefore, the TGM level should be sensitive to the strengthening/weakening of the two monsoons. Once the air flow from high $\mathrm{Hg}$ source regions (Sichuan, Guizhou and Chongqing) is transported to ALS with the strengthening of the EASM, TGM levels at ALS can increase rapidly. However, anthropogenic $\mathrm{Hg}$ emissions from inland China could increase the TGM background level with the raid of westerlies and cold Siberian current during the non-ISM period. Previous studies discussed the seasonal change of TGM at the background sites of southwestern China and found that increased domestic coal consumption and an increase in household heating was the main cause of elevated TGM concentrations observed in winter (Fu et al., 2008, 2010). Additionally, the biomass burning in southeast Asia could also be an important reason for high TGM level at ALS during the non-ISM period. Intense biomass burning originating from southeast Asia typically occurred in late winter and spring (K. Huang et al., 2013). This could be the cause of the high TGM at ALS along with the long-range transboundary transport in the spring (Wang et al., 2015).

Monsoonal distribution patterns and mean TGM, GOM and PBM concentrations based on the four sampling campaigns in ALS are shown in Fig. 5. Mean concentration of 

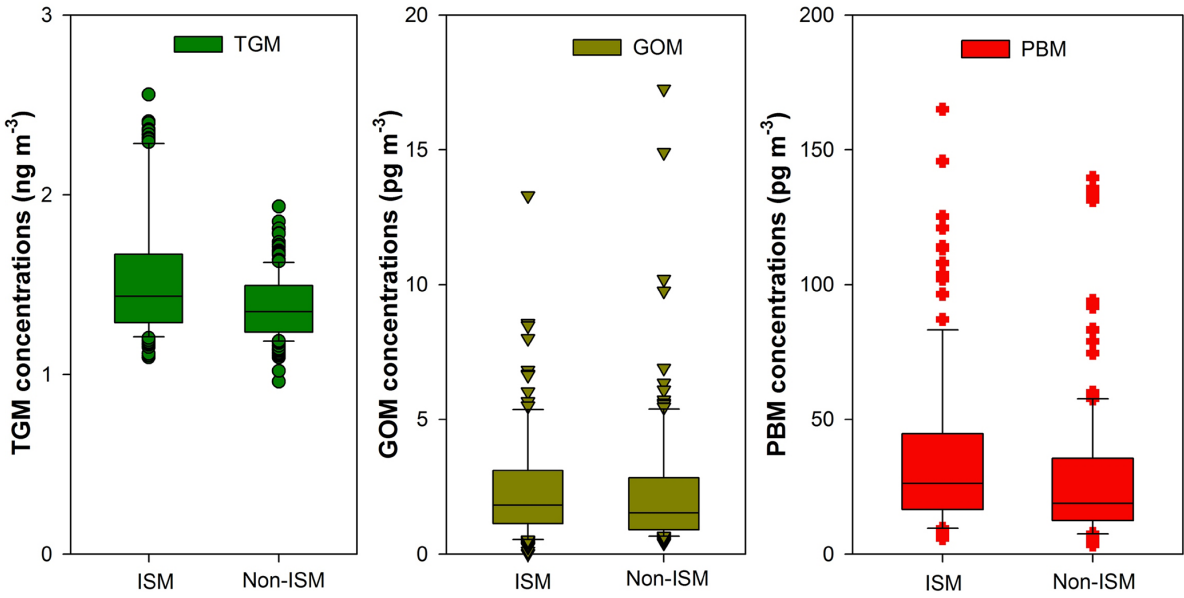

Figure 5. TGM, GOM and PBM variation during the ISM and non-ISM period based on the four sampling campaigns. TGM, GOM and PBM concentrations showed a monsoonal variation with higher level during the ISM period than in the non-ISM period.

the three $\mathrm{Hg}$ species showed a monsoonal variation with higher levels during the ISM period than during the non-ISM period. This suggests that regional anthropogenic emissions are important $\mathrm{Hg}$ sources in southwestern China. During the ISM period, not only was air flow originating from the Indian Ocean dominating but air flow that occasionally originated from the Pacific Ocean also intruded the study site, which passed through central and southwestern China, one of the most Hg-polluted regions. Moreover, the TGM, GOM and PBM levels from the north were higher than those from the south to ALS (Fig. S1 in the Supplement). Thus, the air masses likely captured large amounts of $\mathrm{Hg}$ during transport and caused elevated atmospheric TGM concentrations at ALS during the ISM period.

Figure 6 shows pollution roses of TGM, GOM and PBM at ALS during the ISM period and during the non-ISM period, respectively. The wind direction at the study site was dominantly SW. This reflects that the predominant monsoon influencing the ALS site is the ISM and westerlies. During the ISM period, most of the TGM, GOM and PBM events were from SW, slightly fewer were from NE, and both SW and NE exhibited higher TGM, GOM and PBM events. This indicates that SW and NE were the two primary directions of high $\mathrm{Hg}$ sources during the ISM period. However, during the non-ISM period, almost all TGM, GOM and PBM events were from SW. This indicates that strong westerlies were the primary winds during the non-ISM period. These westerlies could take the GEM and PBM from south Asia and southeast Asia into southwestern China. Thus, the dependence of atmospheric $\mathrm{Hg}$ on wind was likely attributed to an interplay of regional sources and the long-range transboundary transport of the GEM and PBM.

Indeed, GOM concentrations were extremely low at ALS. Marine air masses during the ISM period likely diluted the atmospheric TGM in the study area. The high RF and low WS can promote the wet deposition of GOM and PBM. There- fore, in the summer, RH was very high, but the GOM and PBM were very low at ALS. A new study reported that high $\mathrm{RH}$ could reduce the collection of GOM by the $\mathrm{KCl}$-coated denuder (Huang and Gustin, 2015). This could be another reason why the GOM was low in summer. Additionally, low GOM and PBM could be also related to rapid deposition of $\mathrm{Hg}$ due to the high-altitude montane environment and luxuriant virgin forest cover of Mt. Ailao. A previous study already found that the increasing occurrence and extension of fog and cloud droplet interception can enhance the uptake of $\mathrm{Hg}$ by foliage (Zhang et al., 2013). We will study the possible reasons why the GOM level is exceedingly low in ALS via continuous long-term monitoring for GOM in the future.

\subsection{Transboundary transport of $\mathrm{Hg}$ facilitated by monsoons}

The backward trajectories arriving at ALS over the study period were grouped into five clusters which are shown in Fig. 7. Most of these backward trajectories consisted of air masses that originated from south Asia and southeast Asia, passing over India, the Bay of Bengal, the Indo-China peninsula and the southern Yunnan province of China. Just $4.7 \%$ of air masses originated from inland China and then passed over the Sichuan, Guizhou and Yunnan provinces and the city of Chongqing, China. For the five types of air masses, air masses in cluster 1 displayed very low TGM concentrations $\left(1.86 \mathrm{ng} \mathrm{m}^{-3}\right)$ for all the air masses, although their frequencies were the highest $(38.55 \%)$. Similarly, the mean TGM concentration in cluster 3 was $1.92 \mathrm{ng} \mathrm{m}^{-3}$, which was also considerably low and had the second highest frequency (23.03\%). This suggests that $\mathrm{Hg}$ emitted in south Asia could not have largely contributed to the high TGM levels at ALS. Air masses in cluster 4 showed a high TGM concentration of $2.42 \mathrm{ng} \mathrm{m}^{-3}$, which originated over the South China Sea and passed over northern Vietnam and Laos and the southern 

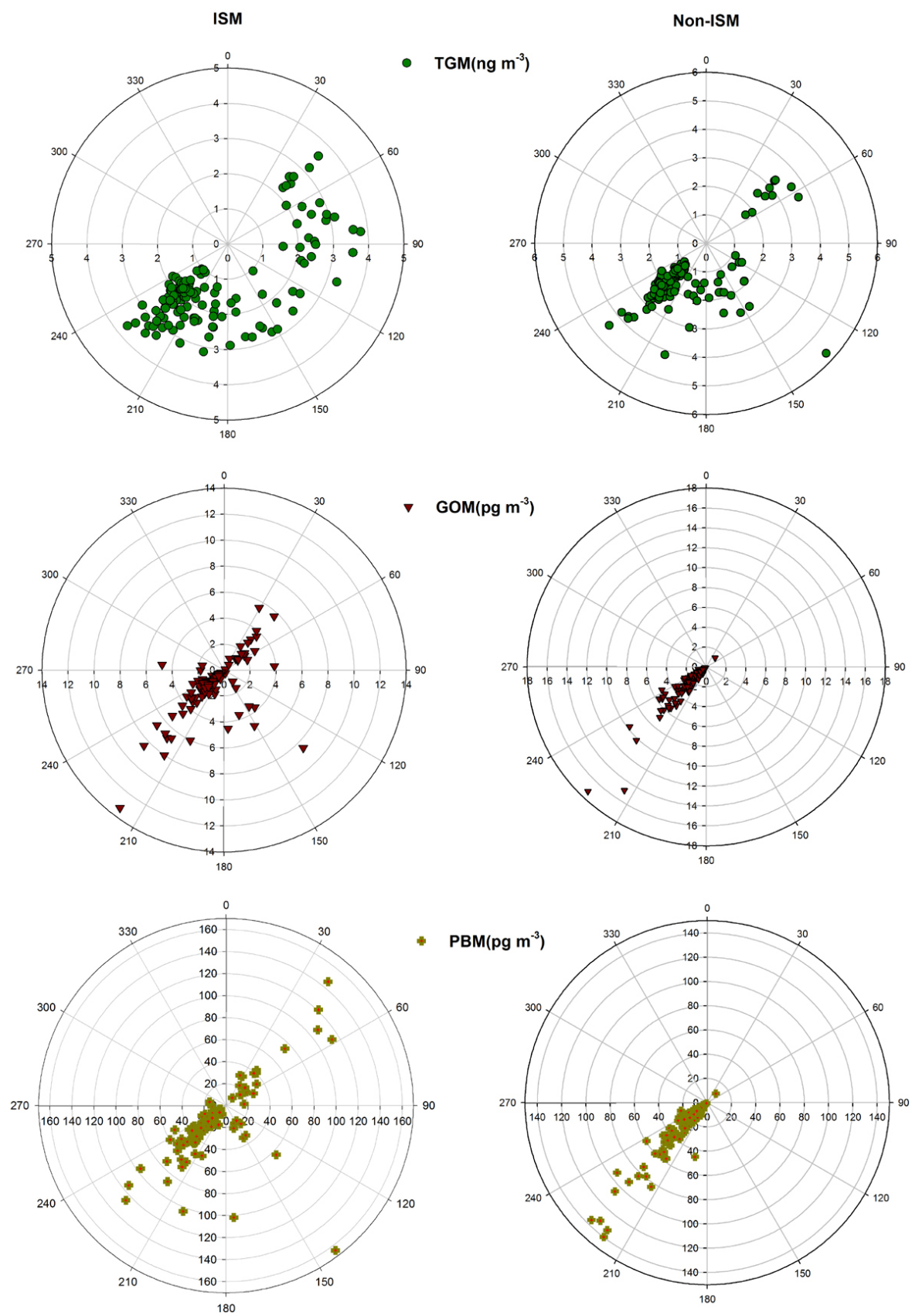

Figure 6. Pollution roses of $\mathrm{Hg}$ species. Most of the TGM, GOM and PBM were from SW, and some higher TGM, GOM and PBM events were from NE during the ISM period. Almost all TGM, GOM and PBM were from SW during the non-ISM period.

Yunnan and Guangxi provinces of China, which are generally areas of less anthropogenic emissions other than biomass burning during the non-ISM period. However, the air masses in cluster 5 were also polluted with $\mathrm{Hg}$, with a mean concentration of $2.20 \mathrm{ng} \mathrm{m}^{-3}$, which is higher than those of clusters 1, 3 and 4. Air flows likely originated in Bengal Bay and passed over Myanmar since most anthropogenic emissions in Myanmar are centralized in southern Myanmar, and intense biomass burning in the area during the non-ISM period perhaps contributed to a slightly high TGM level of these air masses. Cluster 2 displayed the highest TGM concentrations $\left(2.65 \mathrm{ng} \mathrm{m}^{-3}\right)$. Air masses in cluster 2 passed over the inland China region, which is the most densely populated and heavily $\mathrm{Hg}$-polluted area in China due to industrial and domestic coal combustion, smelting industries, cement production, biomass burning, etc. Sichuan, Guizhou, Chongqing and the northwestern Yunnan provinces, respectively, were the contributing $\mathrm{Hg}$ source provinces in China. 


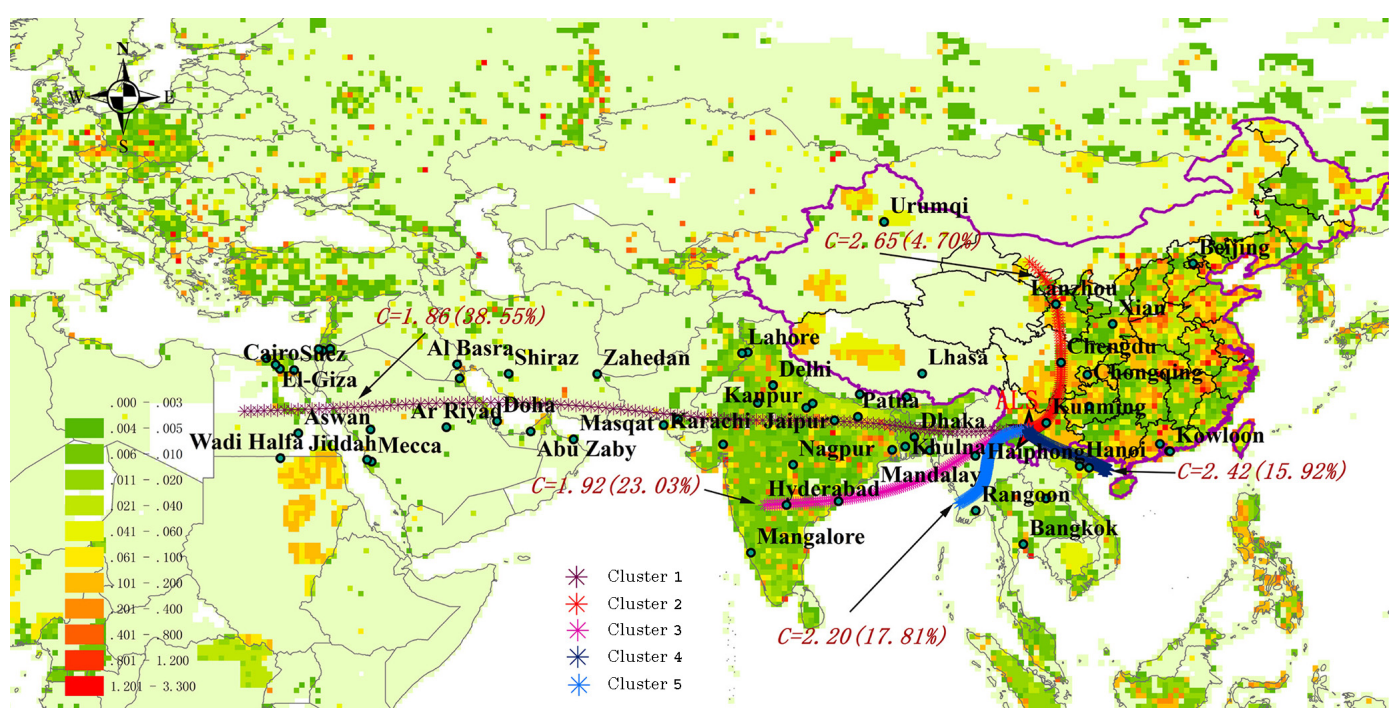

Figure 7. Air mass backward trajectory analysis for long-range transport to ALS. Most of these backward trajectories consisted of air masses that originated from south and southeast Asia and were accompanied by lower Hg levels. Air masses originating from inland China were less frequent and accompanied by higher $\mathrm{Hg}$ levels.

Although only $4.70 \%$ of air masses were from the southwestern China region, the TGM concentrations of these air masses were the highest, which could be an important reason for elevated TGM levels at ALS.

The Tibetan Plateau and Yunnan-Guizhou Plateau are located in north of ALS, which is a monitoring site at high elevation. To the south of ALS, the geography consists of a montane area plain of low elevation. Thus, the air masses at ALS were from different directions and of different heights, which may have affected the TGM level in the air masses as they passed over different anthropogenic emission regions. Figure S2 in the Supplement compares the three-dimensional height of all the wind clusters arriving at ALS. The height of cluster 1 from India was the highest. Such a transport pattern tends to more effectively dilute $\mathrm{Hg}$ emissions from a lowaltitude surface to ALS. Thus, in the non-ISM period, the south tributary of westerlies that passed over India does not lead to elevated TGM concentrations at ALS. Additionally, due to the high TGM concentration in the air in southwestern China, the TGM level of any air masses coming from the northeast of ALS should be increased at ALS regardless of height. Contrarily, cluster 3 had a high height but low-level TGM because its air masses originated and passed over the area of low anthropogenic emission region.

\subsection{Impacts of $\mathrm{Hg}$ emission from industrial sources and biomass burning}

Figure 8 shows the seasonal trend analysis using the average of the daily TGM values, RF distribution, WS and WD during the study period along with IMI (Indian monsoon index) at ALS. In general, May to September represent the normal ISM period. The IMI, however, also illustrates the onset of the ISM in May and its retreat at the end of September. During the ISM period, the mean TGM is $2.22 \mathrm{ng} \mathrm{m}^{-3}$, which is slightly higher than $1.99 \mathrm{ng} \mathrm{m}^{-3}$ during the non-ISM period, and most of the RF events appeared during the ISM period. More crucially, some high-frequency NE and east wind events occurred during the ISM period. Once the WD shifted from SW to NE, the TGM level rapidly increased in addition to relatively lower RF and WS. This indicates that the strengthening of EASM can move the air masses with high TGM levels from inland China to ALS, but when the NE air flow climbed over the Yunnan-Guizhou Plateau, the speed of air mass movement decreased and carried less RF. However, during the non-ISM period, the high TGM events did not accompany the appearance of NE. The WD was primarily SW other than a few SE at the end of March, and the WS was higher than the level during the ISM period. This indicates that the south tributary of westerlies could control the climate and carry air masses from south Asia and southeast Asia. High TGM events were also evident with SW and SE during the non-ISM period, which could be due to $\mathrm{Hg}$ emission from biomass burning in south Asia and southeast Asia.

Therefore, five special high TGM events were accompanied by an exceeding variation of WD and WS to analyze the reasons of high TGM appearance. As Fig. 8 shows, five extreme peaks of high TGM were displayed from 23 29 June and 10-18 July 2011, 28 September to 9 October and 23-31 December 2011, and 23-29 March 2012, respectively. On 23 June, the air masses from India began to increase TGM concentrations, and with the strengthening of the EASM, the TGM level increased gradually and peaked with low RF and WS on 26 June. The air masses that had just swept the Chongqing, Sichuan, Guizhou and eastern Yunnan 


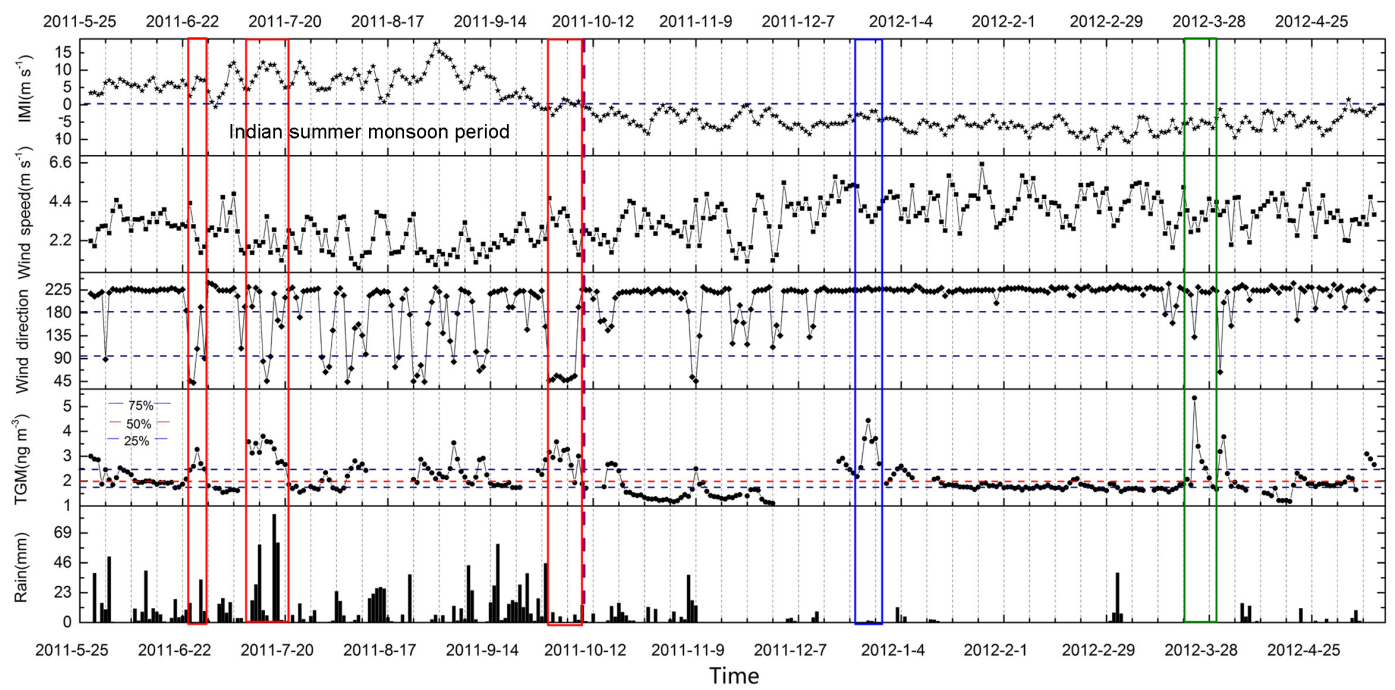

Figure 8. The distribution of the Indian monsoon index (IMI), TGM and rainfall at ALS. IMI displays that the ISM period was from May to September. RF events mainly appeared during the ISM period. Some high Hg events were accompanied by NE and east wind events during the ISM period. High TGM events were accompanied by the appearance of SW during the non-ISM period.

provinces, including Kunming city, where there is high $\mathrm{Hg}$ emission because of industrial activities (Fig. 1). Thus, the air flow from these areas could suddenly increase the TGM level at ALS due to the long-range transport. Once the air flow from EASM faded away, the ISM would control the ALS area again, the air flow would shift to southwest, and the TGM level would return to average levels (Fig. 9a). The same variation appeared from 10-18 July during the ISM period. TGM levels increased on 10 July and were highest $\left(3.65 \mathrm{ng} \mathrm{m}^{-3}\right)$ from $14-16$ July with the strengthening of EASM. When WD shifted to SW, TGM was back to its base level (Fig. 9b). In fact, during the ISM period, this sort of peak appeared many times (Fig. 2); the reason for these peaks was similar to the two peaks in June and July.

However, on 28 September, due to the fadeaway of ISM and the strengthening and incursion of air flow from EASM as well as the cold Siberian current, a high TGM event was initiated as the air flow shifted from SW to NE (Fig. 10). When the air flow swept the Chongqing, Sichuan, Guizhou and eastern Yunnan provinces again from 30 September to 5 October, the TGM level increased to its highest level $\left(3.18 \mathrm{ng} \mathrm{m}^{-3}\right)$, then gradually decreased with the shift in air flow that swept northern Vietnam and Laos. These high TGM events happened during the transitional period from the ISM period to the non-ISM period, which indicates that the high $\mathrm{Hg}$ emission from inland China had severely influenced the TGM level at ALS. As previously discussed, the strengthening of the EASM or the weakening of ISM caused the air flow with high TGM originating from inland China to be transported to ALS, which contributed to extremely high TGM concentrations.

During the non-ISM period, with the fading of the ISM and EASM, the south tributary of westerlies grew stronger as the dry and cold air flow swept over south and southeast Asia and arrived in southwestern China to control the climate. Hence, industrial sources likely contributed to the high-level TGM concentrations in this study site. In Fig. 11, when air masses entered from important southeast Asia industrial regions (e.g., Hanoi, Haiphong), the TGM level was highest $\left(3.13 \mathrm{ng} \mathrm{m}^{-3}\right)$ while TGM concentrations decreased $11 \%$ with the entrance of the strong wind from the Bay of Bengal. In addition, fire events were also observed along the backward trajectories. Moreover, the high correlation $\left(R^{2}=0.89\right)$ between TGM and $\mathrm{CO}$ was identified in Fig. 12. However, the TGM/CO ratio was $0.01124 \mathrm{ng} \mathrm{g}^{-1} \mathrm{ppb}^{-1}\left(1.80 \times 10^{-6} \mathrm{~mol} \mathrm{~mol}^{-1}\right)$, which is more than 10 times higher than the reported world average biomass burning ratio but was close to ratios observed in Taiwan in October $\left(1.28 \times 10^{-6}\right.$, verified from anthropogenic plumes) (Sheu et al., 2010; Friedli et al., 2009). Therefore, in this event, the major contributor should be the industrial sources from southeast Asia. Figure 13 shows that biomass burning is an important source for TGM. On 23 March, the high TGM concentrations began to arise because of the fire events that occurred in northeastern India and north Myanmar. TGM levels were highest $\left(4.53 \mathrm{ng} \mathrm{m}^{-3}\right.$ ) when the air flow shifted and swept inland China. When the air flow shifted from east to southwest and swept south Myanmar from 25-28 March (a period of high-frequency fire events) the TGM concentrations maintained a high level $\left(3.11 \mathrm{ng} \mathrm{m}^{-3}\right)$. However, when the air flow shifted to northern Myanmar, the TGM level returned to low levels $\left(2.01 \mathrm{ng} \mathrm{m}^{-3}\right)$, indicating that biomass burning originating from southeast Asia could also rapidly input and increase the TGM levels in southwestern China during the non-ISM period. Different from Fig. 12, the TGM/CO ratio decreased by 

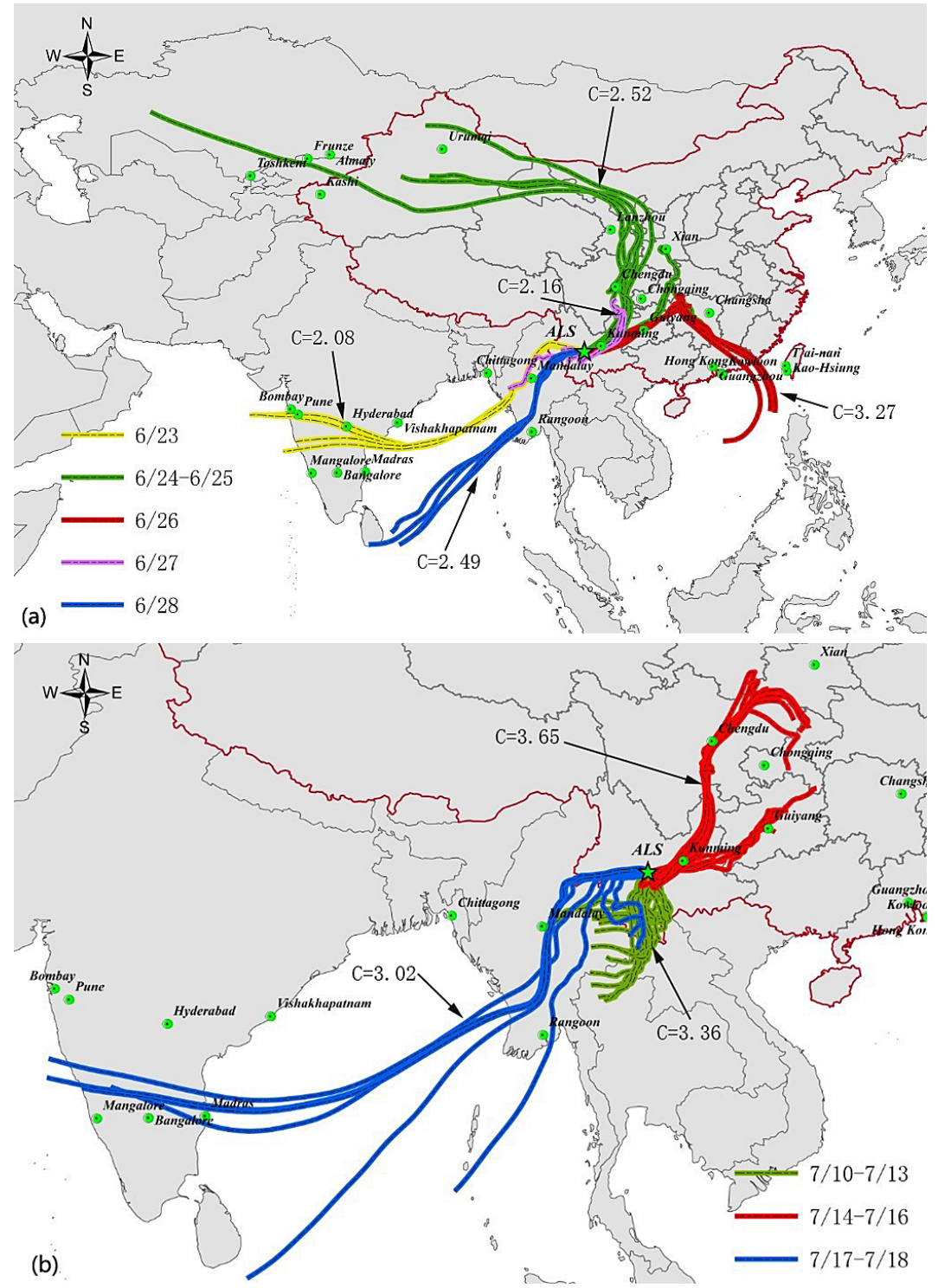

Figure 9. Backward trajectories of air masses and the variation of TGM concentrations because of the strengthening of and incursion of air flow from EASM on 23-28 June 2011 (a), and 10-18 July 2011 (b) during the ISM period (May-September). The TGM levels (C) were $3.27 \mathrm{ng} \mathrm{m}^{-3}$ (a) and $3.65 \mathrm{ng} \mathrm{m}^{-3}$ (b) with the air masses from important industrial regions of inland China. The TGM levels were down to $2.49 \mathrm{ng} \mathrm{m}^{-3}$ (a) and $3.02 \mathrm{ng} \mathrm{m}^{-3}$ (b) while the air flow shifted to southwest and swept southeast Asia.

half in Fig. 14 and was comparable with reported biomass burning ratios $\left(3.00 \times 10^{-7}\right)$ in Canada and the USA (Sigler et al., 2003). Moreover, the close correlations between TFRP (total fire radiative power), which provides information on the measured radiant heat output of detected fires, and $\mathrm{CO}$ $\left(R^{2}=0.98\right)$ and TGM $\left(R^{2}=0.45\right)$ verify the above hypothesis (Wooster et al., 2005).

\subsection{Potential source regions of atmospheric $\mathrm{Hg}$}

Figure 15a shows the possible source regions and pathways of atmospheric TGM at ALS during the ISM period identified by the CWT analysis. The Sichuan, Guizhou,
Chongqing, Yunnan and Guangxi provinces in southwestern China as well as in southeast Asia and northern Laos, Cambodia, Thailand and Vietnam were likely source regions of high atmospheric TGM at ALS during the ISM period. Southwestern China, including the Sichuan, Chongqing, Guizhou and Yunnan provinces, is an important anthropogenic source region of China (Wang et al., 2006; Feng and Qiu, 2008; Wu et al., 2006; Jiang et al., 2006). In fact, several capital cities including Kunming, Guiyang and Chongqing are located about 200 to $800 \mathrm{~km}$ north of ALS. These capital cities may be the source of much of the $\mathrm{Hg}$ emissions during atmospheric transport. The identified source areas corre- 


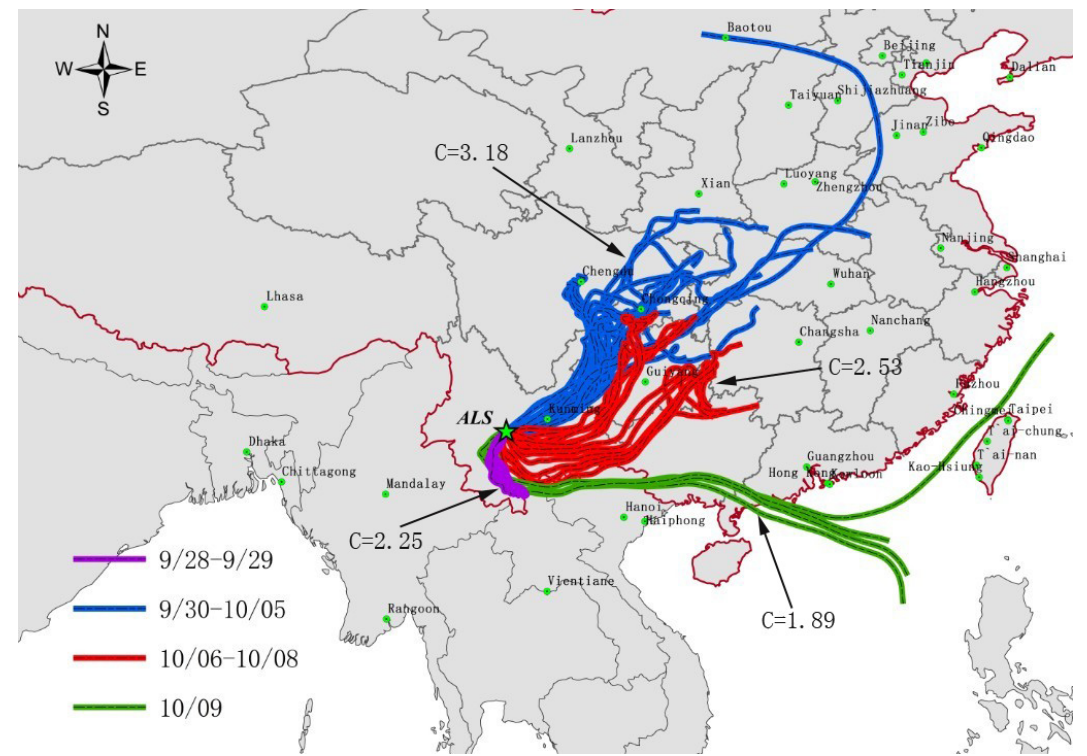

Figure 10. Backward trajectories of air masses and the variation of TGM concentrations because of the strengthening and incursion of air flow from EASM and the cold Siberian current from 28 September to 9 October 2011 during the non-ISM period (October-April). The TGM levels (C) were $2.25,3.18$ and $2.53 \mathrm{ng} \mathrm{m}^{-3}$ with the air masses from inland China. The TGM level was down to $1.89 \mathrm{ng} \mathrm{m}^{-3}$ with the air masses from the South China Sea, northern Vietnam and Laos.

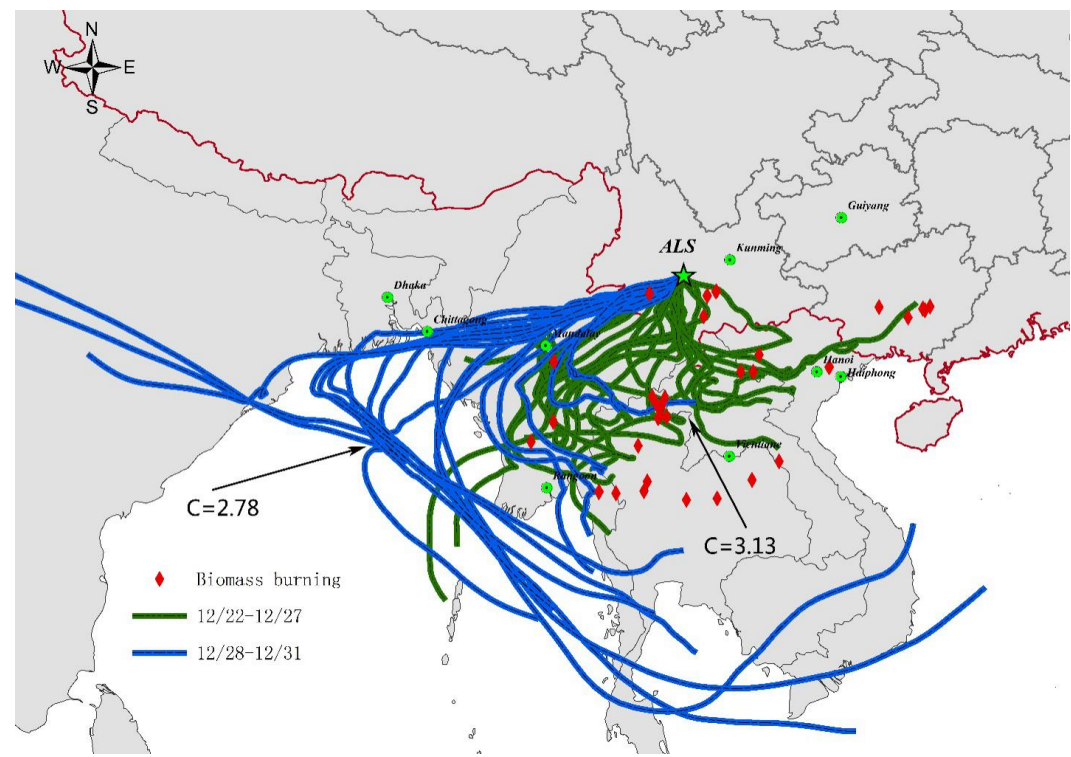

Figure 11. Backward trajectories of air masses and the sites of fire events from 23-31 December 2011, during the non-ISM period (OctoberApril). The TGM level (C) was $3.13 \mathrm{ng} \mathrm{m}^{-3}$ with air masses from important southeast Asia industrial regions. The TGM level dropped to $2.78 \mathrm{ng} \mathrm{m}^{-3}$ with air masses from the Bay of Bengal.

spond very well with the anthropogenic $\mathrm{Hg}$ emission inventories in east and south Asia. The potential area identified in southeast Asia is also classified as a high anthropogenic $\mathrm{Hg}$ emission region by $\mathrm{Hg}$ emission inventories (Pacyna et al., 2010; Pirrone et al., 2010; Li et al., 2009), and the biomass burning in southeast Asia could cause high $\mathrm{Hg}$ emissions. During the non-ISM period, as displayed in Fig. 15b, north- ern India is an important urbanized and industrialized area that may produce high anthropogenic $\mathrm{Hg}$ emission rates, as there are a number of large-scale industries and coal-fired power plants in India (Burger Chakraborty et al., 2013; Pervez et al., 2010). Additionally, the biomass burning in southeast Asia should be a large contributor of high TGM levels at ALS (Wang et al., 2015). A small region in eastern Myanmar 


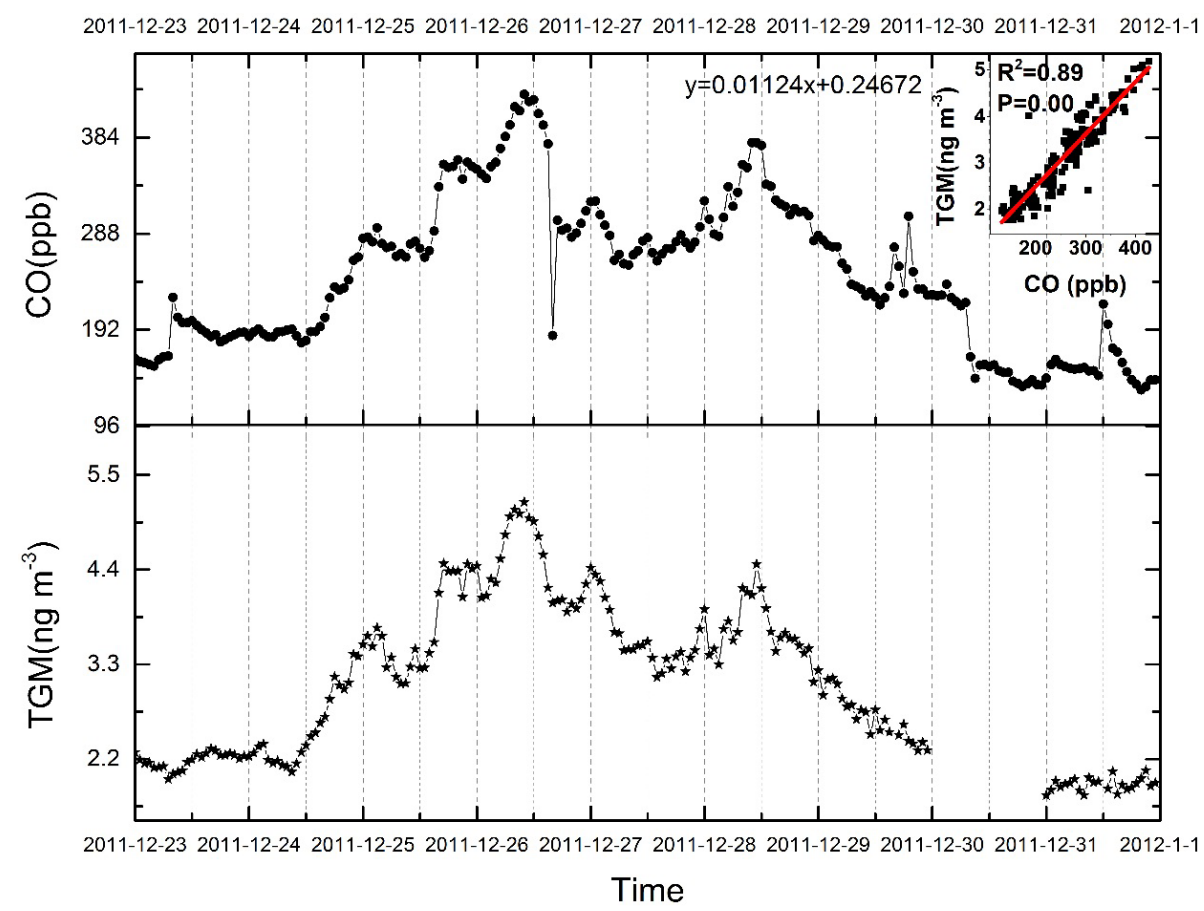

Figure 12. Correlation of TGM and CO in 23-31 December 2011 during the non-ISM period.

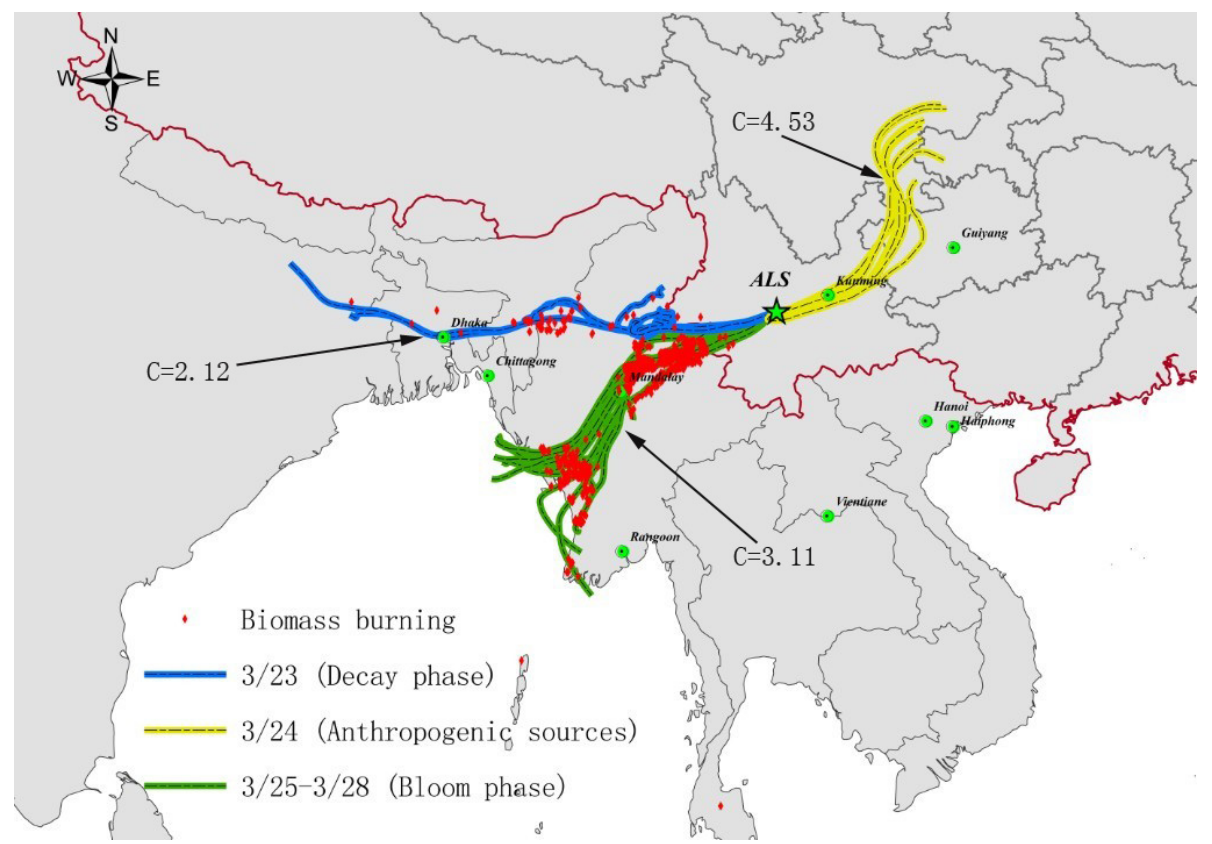

Figure 13. Backward trajectories of air masses and the sites of fire events in 23-29 March 2012 during the non-ISM period (October-April). The TGM level (C) was $4.53 \mathrm{ng} \mathrm{m}^{-3}$ with the air masses from inland China. The TGM level was $3.11 \mathrm{ng} \mathrm{m}^{-3}$ with the air masses from Myanmar and high-frequency fire events.

and northern Laos and Thailand was also identified as a potential source region and pathway for TGM at ALS. The high CWT values in this area may be primarily due to high $\mathrm{Hg}$ emission rates because of biomass burning during the nonISM period.

Indeed, the emission of $\mathrm{Hg}$ from biomass burning includes forest fire and agricultural waste burning in southeast 


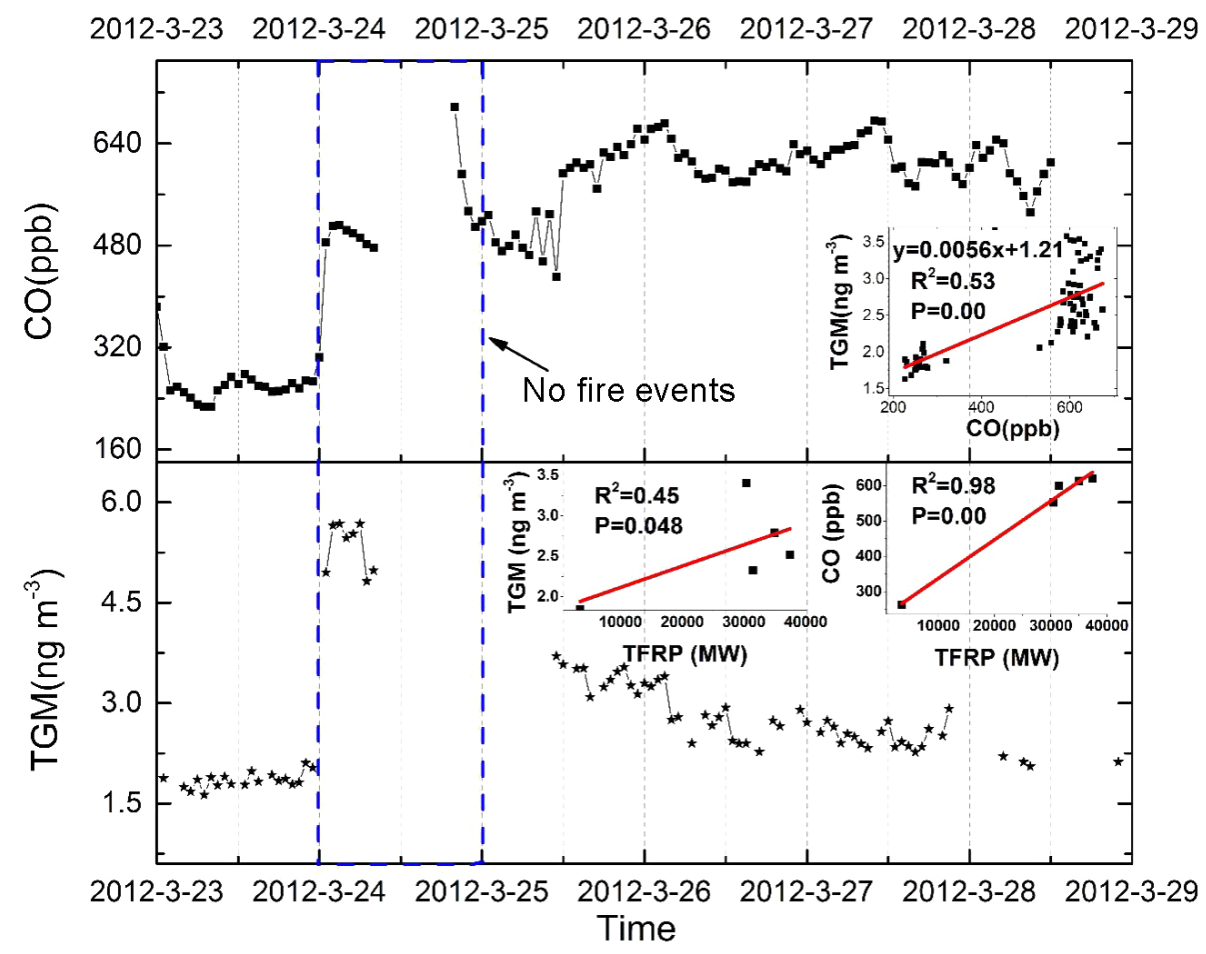

Figure 14. Correlation of TGM and CO $\left(R^{2}=0.53\right)$, correlations between TFRP and CO $\left(R^{2}=0.98\right)$ and TGM $\left(R^{2}=0.45\right)$ in $23-29$ March 2012 during the non-ISM period (October-April).

Asia and southwestern China, and could also play an important role in TGM distribution and transboundary transport at ALS. Southeast Asia and southwestern China are large tropical rain forest areas. During the ISM period, the air had a very high RH and the highest RF. Because the fire events in southeast Asia and southwestern China were not frequent and the biomass burning for agriculture was not prevalent, less $\mathrm{Hg}$ from biomass burning was released into the atmosphere. As shown in Fig. S3a in the Supplement, fire events in southeast Asia and southwestern China during the ISM period (mainly from June to September 2011) exhibited a much lower frequency, indicating that the significant impact of TGM transport was primarily from anthropogenic $\mathrm{Hg}$ emissions. Nevertheless, during the non-ISM period (mainly from December 2011 to April 2012), high-frequency fire events in southeast Asia and southwestern China were observed (Fig. S3b in the Supplement). Hg emissions from fire events peaked when the most intense biomass burning occurred in southeast Asia and southwest China. This increased TGM level at ALS once air masses from these areas were transported to ALS.

\section{Conclusions}

This study made at ALS suggests a significant impact of monsoonal climates on the distribution and long-range transport of atmospheric $\mathrm{Hg}$ in southwestern China and shows a pronounced monsoonal variation with a high TGM level dur- ing the ISM period and a low TGM level during the non-ISM period. This seasonal variation opposes the previous distribution of atmospheric $\mathrm{Hg}$ observed in the background sites of southwestern China. This behavior seems to be dominated by the seasonal variation of monsoons and the influence of the long-range and transboundary transport of $\mathrm{Hg}$ from high anthropogenic $\mathrm{Hg}$ emissions and biomass burning. The high $\mathrm{Hg}$ regional sources from inland China were an important factor in the elevated TGM level. Meanwhile, with the economy developing rapidly, anthropogenic $\mathrm{Hg}$ emission in southeast Asia is also increasing. This will elevate the TGM level in the area, including that of southwestern China. Additionally, $\mathrm{Hg}$ emitted from India can travel to southwestern China due to the ISM in the summer and a strong south tributary of westerlies during cold seasons. Biomass burning includes highfrequency fire events in southeast Asia that could play an important role for high TGM levels during the non-ISM period. Thus, the TGM concentrations during different seasons in addition to the impacts of monsoonal climate may pose an important constraint on the global models of atmospheric $\mathrm{Hg}$.

\section{Data availability}

Requests for data sets and materials should be addressed to Xinbin Feng (fengxinbin@vip.skleg.cn) or Xuewu Fu (fuxuewu@mail.gyig.ac.cn). 

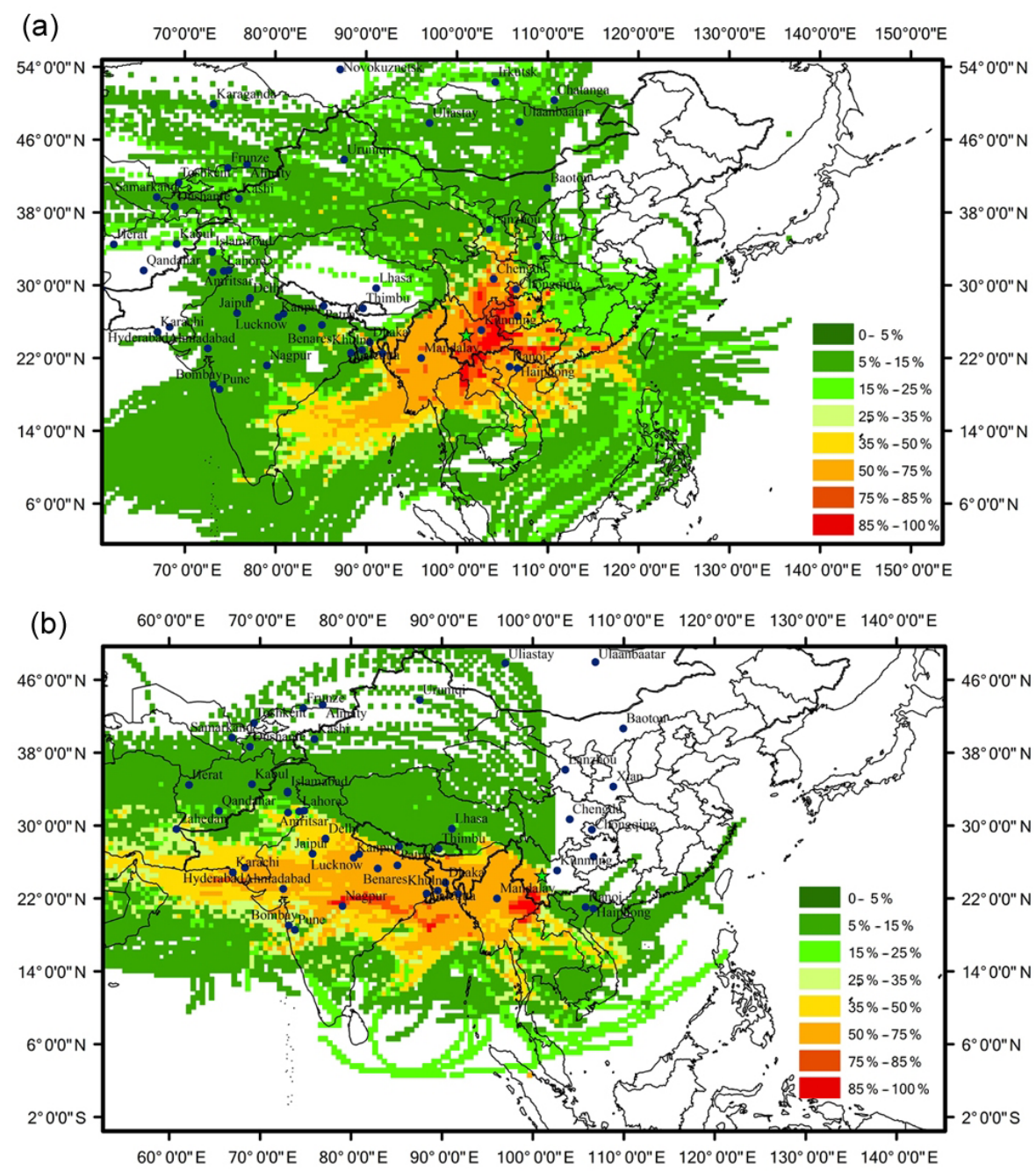

Figure 15. Potential source regions and pathways of atmospheric TGM at ALS as identified by the CWT during the ISM period (a, MaySeptember) and the non-ISM period (b, October-April).

\section{The Supplement related to this article is available online at doi:10.5194/acp-16-13131-2016-supplement.}

Acknowledgements. This work is supported by the National "973" Program of China (2013CB430003), the National Science Foundation of China (41430754, 41473025, 41273145-41173024) and the Global Mercury Observation System (GMOS) as part of FP7 (contract no. 265113) funded by the European Commission. We also thank Xin Luo, Ben Yu and Jun Zhou for field sampling assistance.

Edited by: F. Sprovieri

Reviewed by: two anonymous referees

\section{References}

AMAP/UNEP: Technical Background Report for the Global Mercury Assessment 2013, in: Arctic Monitoring and Assessment Programme, Oslo, Norway/UNEP Chemicals Branch Geneva, Switzerland, 2013.

Bonasoni, P., Laj, P., Marinoni, A., Sprenger, M., Angelini, F., Arduini, J., Bonafè, U., Calzolari, F., Colombo, T., Decesari, S., Di Biagio, C., di Sarra, A. G., Evangelisti, F., Duchi, R., Facchini, M. C., Fuzzi, S., Gobbi, G. P., Maione, M., Panday, A., Roccato, F., Sellegri, K., Venzac, H., Verza, G. P., Villani, P., Vuillermoz, E., and Cristofanelli, P.: Atmospheric Brown Clouds in the Himalayas: first two years of continuous observations at the Nepal Climate Observatory-Pyramid (5079 m), Atmos. Chem. Phys., 10, 7515-7531, doi:10.5194/acp-10-7515-2010, 2010.

Burger Chakraborty, L., Qureshi, A., Vadenbo, C., and Hellweg, S.: Anthropogenic mercury flows in India and impacts of emission controls, Environ. Sci. Technol., 47, 8105-8113, doi:10.1021/es401006k, 2013. 
Chang, S.-S., Lee, W.-J., Wang, L.-C., Lin, N.-H., and ChangChien, G.-P.: Influence of the Southeast Asian biomass burnings on the atmospheric persistent organic pollutants observed at near sources and receptor site, Atmos. Environ., 78, 184-194, doi:10.1016/j.atmosenv.2012.07.074, 2013.

Cheng, I., Zhang, L., Blanchard, P., Dalziel, J., and Tordon, R.: Concentration-weighted trajectory approach to identifying potential sources of speciated atmospheric mercury at an urban coastal site in Nova Scotia, Canada, Atmos. Chem. Phys., 13, 6031-6048, doi:10.5194/acp-13-6031-2013, 2013.

D'Amore, F., Bencardino, M., Cinnirella, S., Sprovieri, F., and Pirrone, N.: Data quality through a web-based QA/QC system: implementation for atmospheric mercury data from the global mercury observation system, Environ. Sci.-Proc. Imp., 17, 14821491, doi:10.1039/c5em00205b, 2015.

Fan, H., Hu, J., and He, D.: Trends in precipitation over the low latitude highlands of Yunnan, China, J. Geogr. Sci., 23, 11071122, doi:10.1007/s11442-013-1066-y, 2013.

Feng, X. and Qiu, G.: Mercury pollution in Guizhou, Southwestern China - an overview, Sci. Total Environ., 400, 227-237, doi:10.1016/j.scitotenv.2008.05.040, 2008.

Feng, X., Sommar, J., Gårdfeldt, K., and Lindqvist, O.: Improved determination of gaseous divalent mercury in ambient air using $\mathrm{KCl}$ coated denuders, Fresenius J. Anal. Chem., 366, 423-428, doi:10.1007/s002160050086, 2000.

Friedli, H. R., Arellano, A. F., Cinnirella, S., and Pirrone, N.: Initial Estimates of Mercury Emissions to the Atmosphere from Global Biomass Burning, Environ. Sci. Technol., 43, 3507-3513, doi:10.1021/es802703g, 2009.

Fu, X., Feng, X., Zhu, W., Wang, S., and Lu, J.: Total gaseous mercury concentrations in ambient air in the eastern slope of Mt. Gongga, South-Eastern fringe of the Tibetan plateau, China, Atmos. Environ., 42, 970-979, doi:10.1016/j.atmosenv.2007.10.018, 2008.

Fu, X., Feng, X., Dong, Z., Yin, R., Wang, J., Yang, Z., and Zhang, H.: Atmospheric gaseous elemental mercury (GEM) concentrations and mercury depositions at a high-altitude mountain peak in south China, Atmos. Chem. Phys., 10, 2425-2437, doi:10.5194/acp-10-2425-2010, 2010.

Fu, X., Feng, X., Liang, P., Zhang, H., Ji, J., and Liu, P.: Temporal trend and sources of speciated atmospheric mercury at Waliguan GAW station, Northwestern China, Atmos. Chem. Phys., 12, 1951-1964, doi:10.5194/acp-12-1951-2012, 2012a.

Fu, X., Feng, X., Shang, L., Wang, S., and Zhang, H.: Two years of measurements of atmospheric total gaseous mercury (TGM) at a remote site in Mt. Changbai area, Northeastern China, Atmos. Chem. Phys., 12, 4215-4226, doi:10.5194/acp-12-42152012, 2012b.

Fu, X. W., Zhang, H., Lin, C. J., Feng, X. B., Zhou, L. X., and Fang, S. X.: Correlation slopes of GEM/CO, GEM/CO $\mathrm{CO}_{2}$, and $\mathrm{GEM} / \mathrm{CH}_{4}$ and estimated mercury emissions in China, South Asia, the Indochinese Peninsula, and Central Asia derived from observations in northwestern and southwestern China, Atmos. Chem. Phys., 15, 1013-1028, doi:10.5194/acp-15-1013-2015, 2015.

Gustin, M. S., Amos, H. M., Huang, J., Miller, M. B., and Heidecorn, K.: Measuring and modeling mercury in the atmosphere: a critical review, Atmos. Chem. Phys., 15, 5697-5713, doi:10.5194/acp-15-5697-2015, 2015.
Hsu, H.-H.: East asian monsoon, in: Intraseasonal Variability in the atmosphere-ocean climate system, Springer, 63-94, doi:10.1007/3-540-27250-X_3, 2005.

Hsu, Y.-K., Holsen, T. M., and Hopke, P. K.: Comparison of hybrid receptor models to locate PCB sources in Chicago, Atmos. Environ., 37, 545-562, doi:10.1016/S1352-2310(02)00886-5, 2003.

Huang, J., Miller, M. B., Weiss-Penzias, P., and Gustin, M. S.: Comparison of gaseous oxidized $\mathrm{Hg}$ measured by $\mathrm{KCl}$-coated denuders, and nylon and cation exchange membranes, Environ. Sci. Technol., 47, 7307-7316, doi:10.1021/es4012349, 2013.

Huang, J. Y. and Gustin, M. S.: Uncertainties of Gaseous Oxidized Mercury Measurements Using KCl-Coated Denuders, Cation-Exchange Membranes, and Nylon Membranes: Humidity Influences, Environ. Sci. Technol., 49, 6102-6108, doi:10.1021/acs.est.5b00098, 2015.

Huang, K., Fu, J. S., Hsu, N. C., Gao, Y., Dong, X., Tsay, S.-C., and Lam, Y. F.: Impact assessment of biomass burning on air quality in Southeast and East Asia during BASE-ASIA, Atmos. Environ., 78, 291-302, doi:10.1016/j.atmosenv.2012.03.048, 2013.

Jiang, G.-B., Shi, J.-B., and Feng, X.-B.: Mercury pollution in China, Environ. Sci. Technol., 40, 3672-3678, doi:10.1021/es062707c, 2006.

Kang, S. C., Huang, J., Wang, F. Y., Zhang, Q. G., Zhang, Y. L., Li, C. L., Wang, L., Chen, P. F., Sharma, C. M., Li, Q., Sillanpaa, M., Hou, J. Z., Xu, B. Q., and Guo, J. M.: Atmospheric Mercury Depositional Chronology Reconstructed from Lake Sediments and Ice Core in the Himalayas and Tibetan Plateau, Environ. Sci. Technol., 50, 2859-2869, doi:10.1021/acs.est.5b04172, 2016.

Kellerhals, M., Beauchamp, S., Belzer, W., Blanchard, P., Froude, F., Harvey, B., McDonald, K., Pilote, M., Poissant, L., and Puckett, K.: Temporal and spatial variability of total gaseous mercury in Canada: results from the Canadian Atmospheric Mercury Measurement Network (CAMNet), Atmos. Environ., 37, 10031011, doi:10.1016/S1352-2310(02)00917-2, 2003.

Kim, K.-H., Ebinghaus, R., Schroeder, W., Blanchard, P., Kock, H., Steffen, A., Froude, F., Kim, M.-Y., Hong, S., and Kim, J.-H.: Atmospheric mercury concentrations from several observatory sites in the Northern Hemisphere, J. Atmos. Chem., 50, 1-24, doi:10.1007/s10874-005-9222-0, 2005.

Kock, H., Bieber, E., Ebinghaus, R., Spain, T., and Thees, B.: Comparison of long-term trends and seasonal variations of atmospheric mercury concentrations at the two European coastal monitoring stations Mace Head, Ireland, and Zingst, Germany, Atmos. Environ., 39, 7549-7556, doi:10.1016/j.atmosenv.2005.02.059, 2005.

Landis, M. S., Stevens, R. K., Schaedlich, F., and Prestbo, E. M.: Development and characterization of an annular denuder methodology for the measurement of divalent inorganic reactive gaseous mercury in ambient air, Environ. Sci. Technol., 36, 3000-3009, doi:10.1021/es015887t, 2002.

Lawrence, M. and Lelieveld, J.: Atmospheric pollutant outflow from southern Asia: a review, Atmos. Chem. Phys., 10, 1101711096, doi:10.5194/acp-10-11017-2010, 2010.

Lee, G. S., Kim, P. R., Han, Y. J., Holsen, T. M., Seo, Y. S., and Yi, S. M.: Atmospheric speciated mercury concentrations on an island between China and Korea: sources and transport pathways, Atmos. Chem. Phys., 16, 4119-4133, doi:10.5194/acp-16-41192016, 2016. 
Lelieveld, J. o., Crutzen, P., Ramanathan, V., Andreae, M., Brenninkmeijer, C., Campos, T., Cass, G., Dickerson, R., Fischer, H., and De Gouw, J.: The Indian Ocean experiment: widespread air pollution from South and Southeast Asia, Science, 291, 10311036, doi:10.1126/science.1057103, 2001.

Li, P., Feng, X., Qiu, G., Shang, L., and Li, Z.: Mercury pollution in Asia: a review of the contaminated sites, J. Haz. Mat., 168, 591-601, doi:10.1016/j.jhazmat.2009.03.031, 2009.

Lin, N.-H., Tsay, S.-C., Maring, H. B., Yen, M.-C., Sheu, G.-R., Wang, S.-H., Chi, K. H., Chuang, M.-T., Ou-Yang, C.-F., and Fu, J. S.: An overview of regional experiments on biomass burning aerosols and related pollutants in Southeast Asia: From BASEASIA and the Dongsha Experiment to 7-SEAS, Atmos. Environ., 78, 1-19, doi:10.1016/j.atmosenv.2013.04.066, 2013.

Lindberg, S., Bullock, R., Ebinghaus, R., Engstrom, D., Feng, X., Fitzgerald, W., Pirrone, N., Prestbo, E., and Seigneur, C.: A synthesis of progress and uncertainties in attributing the sources of mercury in deposition, J. Human Environ., 36, 19-33, doi:10.1579/0044-7447(2007)36[19:ASOPAU]2.0.CO;2, 2007.

Liu, W., Fox, J. E., and $\mathrm{Xu}, \mathrm{Z}$.: Litterfall and nutrient dynamics in a montane moist evergreen broad-leaved forest in Ailao Mountains, SW China, Plant Ecol., 164, 157-170, doi:10.1023/A:1021201012950, 2003.

Liu, W. Y., Fox, J. E. D., and Xu, Z. F.: Nutrient budget of a montane evergreen broad-leaved forest at Ailao Mountain National Nature Reserve, Yunnan, southwest China, Hydrol. Process., 17, 11191134, doi:10.1002/hyp.1184, 2003.

Loewen, M., Kang, S., Armstrong, D., Zhang, Q., Tomy, G., and Wang, F.: Atmospheric transport of mercury to the Tibetan Plateau, Environ. Sci. Technol., 41, 7632-7638, doi:10.1021/es0710398, 2007.

Loewen, M. D., Sharma, S., Tomy, G., Wang, F., Bullock, P., and Wania, F.: Persistent organic pollutants and mercury in the Himalaya, Aqua. Ecosyst. Health Manage., 8, 223-233, doi:10.1080/14634980500220924, 2005.

Mukherjee, A. B., Bhattacharya, P., Sarkar, A., and Zevenhoven, R.: Mercury emissions from industrial sources in India and its effects in the environment, in: Mercury Fate and Transport in the Global Atmosphere, Springer, 81-112, doi:10.1007/978-0-38793958-2_4, 2009.

Pacyna, E. G., Pacyna, J., Sundseth, K., Munthe, J., Kindbom, K., Wilson, S., Steenhuisen, F., and Maxson, P.: Global emission of mercury to the atmosphere from anthropogenic sources in 2005 and projections to 2020, Atmos. Environ., 44, 2487-2499, doi:10.1016/j.atmosenv.2009.06.009, 2010.

Pervez, S., Koshle, A., and Pervez, Y.: Study of spatiotemporal variation of atmospheric mercury and its human exposure around an integrated steel plant, India, Atmos. Chem. Phys., 10, 55355549, doi:10.5194/acp-10-5535-2010, 2010.

Pirrone, N., Cinnirella, S., Feng, X., Finkelman, R. B., Friedli, H. R., Leaner, J., Mason, R., Mukherjee, A. B., Stracher, G., and Streets, D. G.: Global mercury emissions to the atmosphere from natural and anthropogenic sources, in: Mercury fate and transport in the global atmosphere, Springer, 1-47, doi:10.1007/9780-387-93958-2_1, 2009.

Pirrone, N., Cinnirella, S., Feng, X., Finkelman, R., Friedli, H., Leaner, J., Mason, R., Mukherjee, A., Stracher, G., and Streets, D.: Global mercury emissions to the atmosphere from anthro- pogenic and natural sources, Atmos. Chem. Phys., 10, 59515964, doi:10.5194/acp-10-5951-2010, 2010.

Rajgopal, T.: Mercury pollution in India, The Lancet, 362, 18561857, doi:10.1016/S0140-6736(03)14936-7, 2003.

Reid, J. S., Hyer, E. J., Johnson, R. S., Holben, B. N., Yokelson, R. J., Zhang, J., Campbell, J. R., Christopher, S. A., Di Girolamo, L., and Giglio, L.: Observing and understanding the Southeast Asian aerosol system by remote sensing: An initial review and analysis for the Seven Southeast Asian Studies (7SEAS) program, Atmos. Res., 122, 403-468, doi:10.1016/j.atmosres.2012.06.005, 2013.

Schroeder, W. H. and Munthe, J.: Atmospheric mercury - an overview, Atmos. Environ., 32, 809-822, doi:10.1016/S13522310(97)00293-8, 1998.

Sheu, G.-R., Lin, N.-H., Wang, J.-L., Lee, C.-T., Ou Yang, C.-F., and Wang, S.-H.: Temporal distribution and potential sources of atmospheric mercury measured at a high-elevation background station in Taiwan, Atmos. Environ., 44, 2393-2400, doi:10.1016/j.atmosenv.2010.04.009, 2010.

Sheu, G.-R., Lin, N.-H., Lee, C.-T., Wang, J.-L., Chuang, M.-T., Wang, S.-H., Chi, K. H., and Ou-Yang, C.-F.: Distribution of atmospheric mercury in northern Southeast Asia and South China Sea during Dongsha Experiment, Atmos. Environ., 78, 174-183, doi:10.1016/j.atmosenv.2012.07.002, 2013.

Sigler, J. M., Lee, X., and Munger, W.: Emission and longrange transport of gaseous mercury from a large-scale Canadian boreal forest fire, Environ. Sci. Technol., 37, 4343-4347, doi:10.1021/es026401r, 2003.

Slemr, F., Angot, H., Dommergue, A., Magand, O., Barret, M., Weigelt, A., Ebinghaus, R., Brunke, E. G., Pfaffhuber, K. A., Edwards, G., Howard, D., Powell, J., Keywood, M., and Wang, F.: Comparison of mercury concentrations measured at several sites in the Southern Hemisphere, Atmos. Chem. Phys., 15, 31253133, doi:10.5194/acp-15-3125-2015, 2015.

Sprovieri, F., Pirrone, N., Ebinghaus, R., Kock, H., and Dommergue, A.: A review of worldwide atmospheric mercury measurements, Atmos. Chem. Phys., 10, 8245-8265, doi:10.5194/acp10-8245-2010, 2010.

Sprovieri, F., Gratz, L., and Pirrone, N.: Development of a Ground-Based Atmospheric Monitoring Network for the Global Mercury Observation System (GMOS), E3S Web of Conferences, ICHMET 2012, Rome, Italy, 17007, doi:10.1051/e3sconf/20130117007, 2013.

Swartzendruber, P. C., Jaffe, D. A., and Finley, B.: Improved fluorescence peak integration in the Tekran 2537 for applications with sub-optimal sample loadings, Atmos. Environ., 43, 36483651, doi:10.1016/j.atmosenv.2009.02.063, 2009.

Tseng, C., Liu, C.-S., and Lamborg, C.: Seasonal changes in gaseous elemental mercury in relation to monsoon cycling over the northern South China Sea, Atmos. Chem. Phys., 12, 73417350, doi:10.5194/acp-12-7341-2012, 2012.

Venter, A. D., Beukes, J. P., van Zyl, P. G., Brunke, E. G., Labuschagne, C., Slemr, F., Ebinghaus, R., and Kock, H.: Statistical exploration of gaseous elemental mercury (GEM) measured at Cape Point from 2007 to 2011, Atmos. Chem. Phys., 15, 10271-10280, doi:10.5194/acp-15-10271-2015, 2015.

Wang, C., Kim, D., Ekman, A. M., Barth, M. C., and Rasch, P. J.: Impact of anthropogenic aerosols on Indian summer monsoon, 
Geophys. Res. Lett., 36, L21704, doi:10.1029/2009GL040114, 2009.

Wang, D., He, L., Wei, S., and Feng, X.: Estimation of mercury emission from different sources to atmosphere in Chongqing, China, Sci. Total Environ., 366, 722-728, doi:10.1016/j.scitotenv.2005.09.054, 2006.

Wang, X., Zhang, H., Lin, C. J., Fu, X. W., Zhang, Y. P., and Feng, X. B.: Transboundary transport and deposition of $\mathrm{Hg}$ emission from springtime biomass burning in the IndoChina Peninsula, J. Geophys. Res.-Atmos., 120, 9758-9771, doi:10.1002/2015JD023525, 2015.

Wooster, M. J., Roberts, G., Perry, G. L. W., and Kaufman, Y. J.: Retrieval of biomass combustion rates and totals from fire radiative power observations: FRP derivation and calibration relationships between biomass consumption and fire radiative energy release, J. Geophys. Res.-Atmos., 110, D24311, doi:10.1029/2005JD006318, 2005.

Wu, Y., Wang, S., Streets, D. G., Hao, J., Chan, M., and Jiang, J.: Trends in anthropogenic mercury emissions in China from 1995 to 2003, Environ. Sci. Technol., 40, 5312-5318, doi:10.1021/es060406x, 2006.

Xiao, Z., Sommar, J., Wei, S., and Lindqvist, O.: Sampling and determination of gas phase divalent mercury in the air using a $\mathrm{KCl}$ coated denuder, Fresenius J. Anal. Chem., 358, 386-391, doi:10.1007/s002160050434, 1997.

Xu, B., Cao, J., Hansen, J., Yao, T., Joswia, D. R., Wang, N., Wu, G., Wang, M., Zhao, H., and Yang, W.: Black soot and the survival of Tibetan glaciers, P. Natl. Acad. Sci., 106, 22114-22118, doi:10.1073/pnas.0910444106, 2009.

Yao, T., Thompson, L., Yang, W., Yu, W., Gao, Y., Guo, X., Yang, X., Duan, K., Zhao, H., and Xu, B.: Different glacier status with atmospheric circulations in Tibetan Plateau and surroundings, Nature Clim. Change, 2, 663-667, doi:10.1038/nclimate1580, 2012.

You, G., Zhang, Y., Liu, Y., Schaefer, D., Gong, H., Gao, J., Lu, Z., Song, Q., Zhao, J., and Wu, C.: Investigation of temperature and aridity at different elevations of Mt. Ailao, SW China, Int. J. Biometeorol., 1-6, doi:10.1007/s00484-012-0570-6, 2012.
Yu, B., Wang, X., Lin, C. J., Fu, X. W., Zhang, H., Shang, L. H., and Feng, X. B.: Characteristics and potential sources of atmospheric mercury at a subtropical near-coastal site in East China, J. Geophys. Res.-Atmos., 120, 8563-8574, doi:10.1002/2015JD023425, 2015.

Yuhong, Z. K. M. Y. L. and Yourong, L.: Agriculture significance of the foehn effect in the SW monsoon:A case study in the Ailao mountain, J. Mount. Res., 2, 002, 81-87, 1993.

Zhang, G., Li, J., Li, X.-D., Xu, Y., Guo, L.-L., Tang, J.-H., Lee, C. S., Liu, X., and Chen, Y.-J.: Impact of anthropogenic emissions and open biomass burning on regional carbonaceous aerosols in South China, Environ. Poll., 158, 3392-3400, doi:10.1016/j.envpol.2010.07.036, 2010.

Zhang, H., Yin, R.-S., Feng, X.-B., Sommar, J., Anderson, C. W., Sapkota, A., Fu, X.-W., and Larssen, T.: Atmospheric mercury inputs in montane soils increase with elevation: evidence from mercury isotope signatures, Sci. Rep., 3, 3322, doi:10.1038/srep03322, 2013.

Zhang, H., Fu, X. W., Lin, C. J., Wang, X., and Feng, X. B.: Observation and analysis of speciated atmospheric mercury in ShangriLa, Tibetan Plateau, China, Atmos. Chem. Phys., 15, 653-665, doi:10.5194/acp-15-653-2015, 2015.

Zhang, Q. G., Huang, J., Wang, F. Y., Mark, L. W., Xu, J. Z., Armstrong, D., Li, C. L., Zhang, Y. L., and Kang, S. C.: Mercury Distribution and Deposition in Glacier Snow over Western China, Environ. Sci. Technol., 46, 5404-5413, doi:10.1021/es300166x, 2012.

Zhao, D., Yao, P., Yang, R. W., and Cao, J.: The spatial and temporal distribution features of onset period of mean rainy season over Asian monsoon region, Journal of Yunnan University (Natural Sciences Edition), 4, 333-336, 2006. 